\author{
Mieczysław (Celestyn) Paczkowski OFM ${ }^{1}$ \\ Uniwersytet Mikołaja Kopernika w Toruniu \\ Wydział Teologiczny
}

\title{
Wczesnochrześcijańskie rozważania o imieniu Jezus
}

Celem niniejszego opracowania jest zwrócenie uwagi na to, w jakim stopniu wyjaśnianie, rozumienie i wzywanie imienia Zbawiciela stanowiło o wierze rodzącego się Kościoła, jego duchowości i formach kultu.

\section{Wstęp}

Osoba Jezusa stanowiła dla pierwszych pokoleń chrześcijan nieustanny przedmiot refleksji i kultu. Powstawały formuły modlitw pełnych ufności i wiary w moc Syna Bożego. Jednocześnie imię Jezusa było otoczone czcią, wymawiane z szacunkiem, pisane i wyrażane w symbolach. Bywało jednak i tak, że z powodu „prawa tajemnicy” i prześladowań wierni zbyt często nie wymawiali go przed poganami. Kwestie odnoszące się do imienia Jezus nie dotyczą wyłącznie praktyk pobożnościowych lub pism z zakresu duchowości. Świadczą o tym wczesne źródła literackie, dokumentacja epigraficzna i ikonografia.

Wezwanie imienia Jezusa to najprostsza forma wyrażania wiary przez pierwszych chrześcijan (por. 1 Kor 15,3). W sposób wyraźny wskazywała już na to teologia judeochrześcijańska, lecz także gnostycy zaskakują badaczy, głównie jeśli chodzi o uwydatnienie niektórych zagadnień.

W czasach poapostolskich widać wręcz niepodważalność przekonania o historyczności Jezusa. Nie istniał problem historyczności Jego osoby, lecz pytano o tożsamość Jezusa. Wskazywanie na Jego imię stanowiło istotny element przekazu dotyczącego tej refleksji, czyli po prostu był to fundament rodzącej się chrystologii. Absolutna prostota przekazu powodowała, że był on zrozumiały dla wszystkich wierzących. Równocześnie przywoływanie obecności Odkupiciela,

${ }^{1}$ Ojciec dr hab. Mieczysław (Celestyn) Paczkowski OFM, prof UMK — publikował m.in. z następujących dziedzin: patrologia, historia egzegezy (okres patrystyczny), chrześcijańskie wspólnoty na Wschodzie (teologia, historia) i palestynologia. Pracuje w Katedrze Historii Kościoła i Patrologii WT UMK w Toruniu oraz Wyższym Seminarium Duchownym „Antonianum” we Wrocławiu (celestyn@umk.pl). 
w formie prostego i jednoznacznego w swej wymowie przekazu, nie pozostawiało najmniejszych wątpliwości odnośnie do pojmowania Jego osoby i misji.

W późniejszym okresie sposób wyrażania się o Jezusie Chrystusie był już ściśle określony i niepodlegający zmianom. Wszelkie innowacje w tym względzie mogły zmienić sens teologiczny. Refleksja patrystyczna nie uprawomocnia do rozwijania teologii wyłącznie ziemskiego Jezusa. Wątki obecne w tradycji wczesnego Kościoła mają charakter integralny i stanowią wysiłek, by przedstawić Zbawiciela jako konkretną osobę, a zarazem fundamentalną prawdę oraz zasadę hermeneutyczną ${ }^{2}$. „Jezus” to określenie odwołujące do aspektu człowieczeństwa. Na płaszczyźnie hermeneutycznej to znak i warunek zaistnienia w doczesności Syna Bożego przez wcielenie.

Imienia Zbawcy nie sposób odseparować od innych Jego tytułów o charakterze teologicznym. O świadomości historyczności Syna Bożego świadczy brak wyłącznego przywoływania imienia „Jezus” w refleksjach na temat odnoszących się do Niego licznych określeń. U Ojców przyjmowały one formę zarówno rzeczowników, jak i przymiotników czy imiesłowów oraz złożeń wielowyrazowych. W literaturze patrystycznej ich liczba jest imponująca ${ }^{3}$. Imię podkreślało człowieczeństwo Syna Bożego ${ }^{4}$. Ojcowie Kościoła, idąc śladem autorów Nowego Testamentu, do imienia „Jezus” dodawali określenia, które wyrażały wiarę w Jego bóstwo i uwydatniały Jego posłannictwo. W teologii patrystycznej nie ma refleksji, które mogłyby być zalążkiem współczesnej ,jezulogii”`.

Dobrą syntezę tematyki imienia Zbawiciel stanowią hasła w encyklopediach i słownikach specjalistycznych ${ }^{6}$. Przy badaniu źródeł literackich i dokumentacji epigraficznej w XX wieku, tacy autorzy, jak Jean Daniélou ${ }^{7}$ czy Emanuel Testa z Bellarminem Bagattim ${ }^{8}$, zwracają uwagę na refleksję dotyczącą imienia Jezu-

2 Por. C. Bartnik i in., Jezus Chrystus, EK, t. 7, Lublin 1997, kol. 1287-1442, tu: kol. 1287.

${ }^{3}$ Szacunkowe liczby u niektórych autorów chrześcijańskich późnej starożytności (Klemens Aleksandryjski, Ambroży z Mediolanu, Augustyn z Hippony, Leon I Wielki, Grzegorz I Wielki) podaje F. Drączkowski w Jezus Chrystus - nazwy (zob. C. Bartnik i in., Jezus Chrystus, kol. 1353).

${ }^{4}$ Już autorzy natchnieni używali go, mówiąc o Jezusie jako człowieku. Imię pojmowano przecież jako odnoszące się do konkretnej osoby, ją indywidualizujące.

${ }_{5}^{5}$ Odnośnie do tej kwestii por. A. Nossol, Jezulogia, EK, t. 7, Lublin 1997, kol. 1285-1287.

${ }^{6}$ Cytowane są tylko te najważniejsze z punktu widzenia podjętej tematyki.

${ }^{7}$ Por. J. Daniélou, Sacramentum futuri. Les figures du Christ dans Ancien Testament. Études sur les origines de la typologie biblique, (Études de Théologie Historique), Paris 1950; tenże, Théologie du judéo-christianisme. Histoire des doctrines chrétiennes avant Nicée, (Bibliotheque du Théologie), Paris 1958; tenże, Les symboles chrétiens primitifs, Paris 1963. W artykule wykorzystano thumaczenie własne.

${ }^{8}$ Obaj uczeni franciszkańscy opracowali syntezę historii i doktryny sekt judeochrześcijańskich. Opracowania Bagattiego i Testy wzbudzały nierzadko sceptycyzm niektórych uczonych, oskarżających franciszkańskich badaczy o błędy metodologiczne w ocenie znalezisk. Jest jednak znamienne, że wielu archeologów przyjęło przychylnie interpretację znalezisk i miejsc kultu. Por. B. Bagatti, The Church from the Circumcision. History and Archaeology of the Judaeo-Christians 
sowego w teologii i kulcie judeochrześcijańskim. Ich studia są szeroko znane, a z publikacji autorstwa tych uczonych czy ich „szkoły” czerpano pełnymi garściami, chociaż szczególnie o. Testa był często i nader chętnie kontestowany9

Kwestie paleograficzne stały się przedmiotem pogłębionych analiz, gdy w kolejnych dekadach refleksję tę kontynuowano. Przekonują o tym opracowania, które wyszły spod pióra Larry'ego W. Hurtado. W sposób kompleksowy autor ten wskazał, że literom tworzącym imię „Jezus” nadawano symboliczne znaczenie, ponieważ należało ono do grupy ,świętych nazw" (nomina sacra) ${ }^{10}$.

Odnośnie do znaczenia teologicznego imienia „Jezus” pojawiają się wzmianki w studiach nad tekstami biblijnymi i nad historią egzegezy chrześcijańskiej ${ }^{11}$. Należy jednak pamiętać, że tego typu opracowania raczej pobieżnie zajmują się myślą patrystyczną. Jest tak być może ze względu na przekonanie o wszechobecności i dominacji wątków duchowych i kaznodziejskich w literaturze chrześcijańskiej tego okresu. Jednak można wykazać, że refleksja pisarzy wczesnego Kościoła jest odbiciem tego, co Pismo Święte mówi o imieniu Zbawiciela ${ }^{12}$, a co w jakimś stopniu podejmują współczesne komentarze biblijne lub opracowania egzegetyczno-teologiczne.

Stosuje się metodę syntetyczną w połączeniu z opracowaniem chronologicznym, by móc uwydatnić obecność i rozwój pewnych wątków na przestrzeni czasu. W zasadzie, chociaż z nielicznymi wyjątkami, nie wykracza się poza $\mathrm{V}$ wiek. Chodzi przede wszystkim o przykłady hagiograficzne i niektóre refleksje duchowe. Wiele pobocznych problemów nie jest głębiej analizowanych, a jedynie są

(Studium Biblicum Franciscanum - Collectio Minor 2), Jerusalem 1984; E. Testa, Il simbolismo dei giudeo-cristiani (Studium Biblicum Franciscanum - Collectio Maior 14), Jerusalem 1981; tenże, The Faith of the Mother Church. An Essay on the Theology of the Judeo-Christians, trans. P. Rotondi, Jerusalem 1992.

${ }_{9}^{9}$ Obiekcje różnego typu relacjonuje J.E. Taylor, Christians and Holy Places. The Myth of Jewish-Christian Origins, Oxford 1993.

${ }^{10}$ Por. L.W. Hurtado, The Origin of the Nomina Sacra: A Proposal, „,ournal of Biblical Literature" 117 (1998) 4, s. 655-673; tenże, The Earliest Evidence of an Emerging Christian Material and Visual Culture: The Codex, the Nomina Sacra and the Staurogram [w:] Text and Artifact in the Religions of Mediterranean Antiquity. Essays in Honour of Peter Richardson, ed. S.G. Wilson, M. Desjardins, Waterloo (Ontario) 2000, s. 271-288; tenże, Homage to the Historical Jesus and Early Christian Devotion, „Journal for the Study of the Historical Jesus” 1-2 (2003), s. 131-146; tenże, The Earliest Christian Artifacts. Manuscripts and Christian Origins, Grand Rapids 2006; tenże, Early Devotion to Jesus. A Report, Reflections and Implications, „Expository Times” 122 (2011) 4, s. 167-176.

${ }^{11}$ Tytuły chrystologiczne w apozycji w stosunku do imienia „Jezus” omawia A. Piwowar, Apozycja tytułów chrystologicznych i imienia ,Jezus”, „Biblica et Patristica Thoruniensia” 8 (2015) 2, s. 111-128. Z kolei o utożsamieniu ,zbawienia” z „uzdrowieniem” zob. J. Moles, Jesus the Healer in the Gospels, the Acts of the Apostles, and Early Christianity, „Histos” 5 (2011), s. 117-182.

12 Zob. syntezę w: F. Zorell, Lexicon Graecorum Novi Testamenti, Paris 1961³ , s. 608; H. Ordon, Imię Jezus, EK, t. 7, Lublin 1997, kol. 63-64. 
sygnalizowane. Nie wzięto pod uwagę licznych powtórzeń, często pojawiających się w pismach starochrześcijańskich ${ }^{13}$. Trudno także było na potrzeby artykułu sporządzać listę wzmianek o imieniu Jezusa z nawiązaniem do misji Zbawcy ${ }^{14}$ czy też cytować przykłady synonimicznego użycia określeń Jego osoby.

\section{Homonimia Jozue-Jezus}

Jezus jest imieniem własnym Syna Bożego, zrodzonego z Maryi „za sprawą Ducha Świętego"15. Aż do II wieku po Chr. w kręgach judaistycznych imię

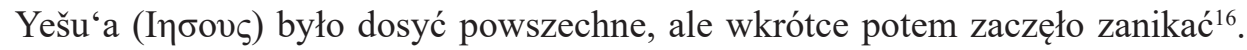
W rodzącym się chrześcijaństwie zwrócono uwagę na zbieżność imion „Jozue” i „Jezus” ('I $\rceil \sigma o \tilde{\varsigma} \varsigma)^{17}$, gdyż zarówno podobieństwo imion, jak i ich etymologiczne znaczenia („Bóg zbawia”) ${ }^{18}$, stanowiły ważny element typologii chrystologicznej $^{19}$ i polemiki antyjudaistycznej ${ }^{20}$. W kulturze semickiej, jak również wśród innych ludów starożytności, imię określało istotę osoby lub rzeczy, odsłaniało jej charakter i przeznaczenie tego, kto je nosił ${ }^{21}$. Na tej podstawie, mimo ograniczonej rozpiętości i rozdrobnienia materiału, pojawiło się wiele ważnych przy-

${ }^{13}$ Bynajmniej nie roszczę sobie prawa do tego, by w pełni wyczerpać tę obszerną tematykę.

${ }^{14} \mathrm{Na}$ temat misji zbawczej Jezusa por. H. Langkammer, Obraz Chrystusa Zbawcy w listach pasterskich, „Questiones selectae” 25 (2010), s. 23-45, tu: s. 41-43; A. Piwowar, Apozycja tytułów chrystologicznych..., s. 123-124.

${ }^{15}$ Jednoznacznie wskazują na to teksty: Łk 1,31 i 2,21. Potwierdza to również Mt 1,21.25. Niewidomy od urodzenia, którego Zbawca uzdrowił, określił Go jako „człowieka zwanego Jezusem" (J 9,11). W tekście Mateusza dopatrywano się wskazania na Jezusa jako zamykającego czas oczekiwań eschatologicznych i mesjańskich a otwierającego pełnię czasów przez realizację zawartego w samym imieniu posłannictwa. Mesjasz jest Zbawicielem, Emanuelem, znakiem obecności Boga pośród swego ludu, a Jego narodzenie zapoczątkowało ową zbawczą obecność Boga.

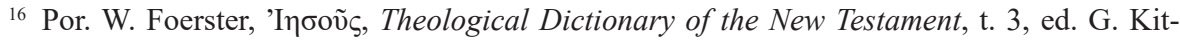
tel, Grand Rapids 1995, s. 284-293, tu: s. 285-286; K.H. Rengstorf, 'I Dictionary of New Testament Theology, t. 2, ed. C. Brown, Grand Rapids 1986², s. 330-332, tu: s. 331-332.

${ }^{17}$ Imię „Jozue” (gr. Jezus) nie było rzadkie w starożytnej historii Izraela. Jeden ze współpracowników św. Pawła nazywał się Jesùs (Kol 4,11). Historyk żydowski Józef Flawiusz wspomina o około tuzinie osób tego imienia, niezwiązanych z tekstem biblijnym. W tradycji łacińskiej, w celu podkreślenia najwyższej pozycji Jezusa, następcę Mojżesza nazwano Jozuem. Jednak w tradycji greckiej (a w ślad za nią w prawosławiu) pozostano przy jedynym brzmieniu tego imienia, nazywając następcę Mojżesza Jezusem, synem Nuna (Nawego).

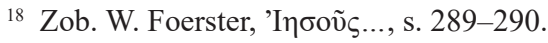

19 Jest to widoczne szczególnie u Orygenesa, por. K. Bardski, Chrystologiczna interpretacja Księgi Jozuego u Orygenesa, „Collectanea Theologica” 84 (2015) 4, s. 197-202.

${ }^{20}$ Por. A Dictionary of the Targumim, the Talmud Babli and Yerushalmi and the Midrashic Literature, ed. M. Jastrow, t. 1, London-New York 1903, s. 599-600.

${ }^{21}$ R. de Vaux, Instytucje Starego Testamentu, t. 1, tłum. T. Brzegowy, Poznań 2004, s. 53-54. 
czynków, wskazujących na sięganie po inspirującą kwestię dotyczącą imienia Zbawiciela ${ }^{22}$. Te wątki refleksji egzegetycznej pojawiły się wtedy, gdy na dobre trwał konflikt chrześcijaństwa $\mathrm{z}$ judaizmem ${ }^{23}$, chociaż jej zalążki są już w tekstach nowotestamentowych ${ }^{24}$. Kryterium początkującym refleksję chrystologiczną w większości tekstów patrystycznych była historia zbawienia. Imię Jezus określało Słowo Wcielone i realizację Jego posłannictwa odkupienia. Na te tory miała naprowadzić typologia Jozue-Jezus ${ }^{25}$.

W sposób wyraźny odwołanie do Jozuego jako „typu” Zbawiciela występuje w traktacie przypisywanym Barnabie (ok. 130 r.). Autor wykorzystuje judaistyczną tradycję zmiany imienia „Ozeasz” na „Jozue”26. Warto zaznaczyć, że ten fragment stanowi część parafrazy opisu walki Jozuego z Amalekitami (por. Wj 17) ${ }^{27}$. Syn Nuna jest więc zapowiedzią prawdziwego Zbawiciela, Syna Bożego, który „zbawi swój lud od jego grzechów” (Mt 1,21). Epistula Barnabae wskazuje na to, że przez długi czas egzegeza chrześcijańska Starego i Nowego Testamentu opierała się na antologiach tekstów biblijnych zwanych Testimonia, nie zaś na systematycznych komentarzach ksiąg biblijnych. Poszczególne wersety lub perykopy grupowano według tematyki teologicznej z myślą o głównych wątkach katechezy ${ }^{28}$.

Jeszcze wyraźniejsze są nawiązania do postaci Jozuego w polemice antyjudaistycznej Justyna z Nablus. Apologeta pisze: „Ten, który doprowadził waszych ojców do tej ziemi [Kanaan], został nazwany imieniem «Jezus», a najpierw nazywano go «Joszua». Jeśli bowiem to zrozumiecie, będziecie mogli pojąć, że imię Tego, który powiedział do Mojżesza «gdyż moje imię jest w Nim» brzmiało

${ }^{22}$ Por. M. Szram, Jezus Chrystus — dzieje (zob. C. Bartnik, Jezus Chrystus ..., kol. 1320).

${ }^{23}$ Już Septuaginta bardziej akcentowała rolę Jozuego niż tekst hebrajski. Teksty rabinackie porównywały Mojżesza do słońca, a Jozuego do księżyca, co, jak się wydaje, było reakcją na typologię chrześcijańską. Por. J. Moatti-Fine, La Bible d'Alexandrie, t. 6: Jesus (Josue), Paris 1996, s. 25-26; A. Tronina, Jozue-Jezus. Biblijna typologia Zbawiciela, „Verbum vitae” 1 (2002), s. 4156, tu: s. 49.

${ }^{24}$ Nowy Testament odnosi się do imienia wodza Izraelitów w Hbr 4,8 i w Dz 7,45. W tekście Listu do Hebrajczyków autor wskazuje na antytezę: Jozue/Chrystus. Ten pierwszy „nie wprowadził ich do odpoczynku” (Hbr 4,8), a Zbawiciel ,przeszedł przez niebiosa” (Hbr 8,14). Na temat osoby Jozuego, syna Nuna w judaizmie i Nowym Testamencie por. A Dictionary..., s. 566; F. Zorell, Lexicon..., s. 609.

25 Por. M.C. Paczkowski, Przejście Izraelitów przez Jordan (Joz 3-4) w interpretacji patrystycznej, „Biblica et Patristica Thoruniensia” 8 (2015), s. 39-73, tu: s. 47-49.

26 „Mówi więc Mojżesz do Jezusa syna Nawe, nadając mu to imię w chwili, gdy posyła go dla zbawienia kraju [...]. Oto znowu objawiony w cielesnej zapowiedzi Jezus, nie syn człowieka, ale Syn Boga"; Epistula Barnabae XII, 8, SCh 172, s. 170-173, tłum. A. Świderkówna, BOK 10, s. 195.

${ }^{27}$ Por. Epistula Barnabae XII, 8-9. Już w judaizmie Amalekici symbolizowali moce diabelskie.

${ }^{28}$ Systematyczne komentarze pojawiają się dopiero w czasach Hipolita i Orygenesa. Z czasem kolekcje tekstów biblijnych uzupełniano o sposób interpretacji. 
«Jezus»" ${ }^{29}$. Z kolei poganom ten filozof i męczennik wyjaśniał, że „Jezus to imię hebrajskie, które po grecku znaczy «Zbawiciel». Z tego powodu anioł powiedział do Dziewicy: «Nazwiesz go imieniem Jezus, bowiem on zbawi swój lud od jego grzechów» (Łk 1,32)"30.

Justyn zwraca uwagę na to, że pierwsze litery imienia „Jozue” Mojżesz zapożyczył z imienia Jahwe. „Jezusa [Jozuego], jak już często powtarzałem, tego samego, który nazywał się «Auses» (Ozeasz) [...], Mojżesz nazwał «Jezusem». Ty zaś nie pytasz o to, dlaczego tak uczynił [...]! A zatem o Chrystusie nic nie wiesz, a jeśli czytasz, nie rozumiesz"31. W otwartej polemice apologeta udowadnia, że Jozue był większy od Mojżesza, choć ten ostatni dla Żydów nie miał sobie równych ${ }^{32}$.

Jak się wydaje, w polemice z gnostykami postać Jozuego nie odgrywała kluczowej roli, jak to było w dyskusjach z Żydami. Ireneusz z Lyonu rozważa dzieje syna Nuna w spokojnym kontekście katechetycznej nauki Demonstratio. Mojżesz zmienił jego imię i ,nazwał go imieniem Jezus. I tak wysłał go w mocy tego imienia wierząc, że będzie ich mógł przyjąć na powrót ocalonych, gdyż prowadziło ich to imię. I tak się też stało"33.

Dla Orygenesa czyny Jozuego były zapowiedzią zbawczych dzieł Chrystusa. Zbieżność imienia skłania Aleksandryjczyka do tego, by księgę o następcy Mojżesza odczytywać jako proroctwo o Panu Jezusie. „Księga Jozuego — pisał Adamancjusz - nie tyle opowiada o czynach syna Nawego, co raczej maluje nam tajemnice dotyczące [...] Jezusa"34. Sens imienia Jozuego był zrealizowany i urzeczywistniony podjętymi przez niego działaniami w harmonijnej współpracy z Bogiem. Historia syna Nuna jest więc rodzajem praeparatio evangelica remota. Osią refleksji Orygenesa nad postacią Jozuego jest typologia historyczna, skupiona na odniesieniach Jozue-Jezus Chrystus. Chodzi zarówno o perspekty-

29 Justyn, Dialogus cum Tryphone 75, PG 6, 652 A-B, thum. L. Misiarczyk, s. 244-245. Zob. także 89.

${ }^{30}$ Justyn, I Apologia 33, 7, PG 6, 381 C, tłum. L. Misiarczyk, s. 65.

31 Justyn, Dialogus cum Tryphone 113, 1, PG 6, 736 B, thum. L. Misiarczyk, s. 285-286. Por. G. Otranto, La tipologia di Giosué nel „Dialogo con Trifone ebreo” di Giustino, „Augustinianum” 15 (1975) $1 / 2$, s. 29-48.

${ }^{32}$ Poza oficjalnym rabinizmem postać Jozuego była wręcz gloryfikowana. Filon z Aleksandrii uwydatnia, że zmiana imienia z Ozeasz („Zbawiony”) na Jozue („Zbawienie Pana”) ma wyrażać cechę wieczną i doskonałą, przewyższającą śmiertelnego człowieka (zob. De mutatatione 121122). Podobnie Józef Flawiusz kreśli obraz Jozuego jako dzielnego dowódcy, który również w czasach pokoju był „zręcznym rządcą” (por. Antiquitates Judaicae V, 36). Wg Liber Antiquitatum Biblicarum Pseudo-Filona (koniec I w. po Chr.) Jozue to natchniony duchem proroczym następca Mojżesza (za: A. Tronina, Jozue-Jezus, s. 49).

${ }^{33}$ Ireneusz z Lyonu, Demonstratio 27, SCh 62, s. 76, tłum. W. Myszor, ŹMT 7, s. 47. Biskup Lyonu przywołuje Lb 13,23-24.

34 Orygenes, Homeliae in librum Jesu Nave I, 3, SCh 71, s. 100-101, PSP 34/2, s. 6. Homileta odwołuje się do Wj 17,8-13 i Kol 2,14-15. 
wę horyzontalną (obietnice i ich wypełnienie), jak i wertykalną (rzeczywistość ziemska stanowi cień rzeczy nadprzyrodzonych ${ }^{35}$. Linie tematyczne splatają się z sobą, tworząc także całą gamę zagadnień pochodnych ${ }^{36}$. Wiodącym wątkiem jest u Adamancjusza kwestia wyższości Zbawiciela nad Jozuem. Nie ulega wątpliwości, że to sam Bóg ukazał tę prawdę. Jozue nakazał obrzezanie, które było zapowiedzią prawdziwego znaku chrztu. „Chrystus zajął miejsce Mojżesza, Tym, który posiada pierwszeństwo nie jest Jozue, syn Nuna, lecz Jezus, Syn Boży”37. Jozue jest więc ,pierwotypem Jezusa Chrystusa, który przez głoszenie nauki ewangelicznej stał się następcą w zarządzaniu Prawem”38.

Podobnych informacji dostarcza Tertulian, lecz już w innym kontekście: chodzi o polemikę z Marcjonem i jego kontynuatorami ${ }^{39}$. Afrykańczyk pisze: „Syna Nuna (Ozeasza) [...] zaczęto nazywać imieniem Jezus [...]. To imię było wpierw figurą przyszłego imienia. Bo Jezus Chrystus miał wprowadzić drugi naród, którym my jesteśmy jako urodzeni na pustyni świata, do ziemi obietnic, mlekiem i miodem płynącej, to jest do osiągnięcia życia wiecznego [...]. To miało dokonać się nie przez Mojżesza, to jest przez karność Prawa, ale przez Jezusa, czyli przez łaskę Ewangelii” ${ }^{40}$. Wysłannik Boży został nazwany Jezusem ,ze względu na tajemnicę Jego przyszłego imienia"41. Czyny Jozuego wpisywały się w ciąg wydarzeń zbawczej historii, chociaż w przypadku tej postaci pisarze chrześcijańscy odstępowali od tradycyjnej typologii dotyczącej Starego Testamentu i judaizmu $^{42}$.

W epoce ponicejskiej typologia postaci Jozuego była już wyraźnie ustalona. Świadczą o tym cykle ikonograficzne, w których typologia Jozue-Jezus zostawiła bogate ślady ${ }^{43}$. Podobnie, jak we wcześniejszym okresie ułatwiał to fakt, że

35 Por. R. Scognamiglio, Giosue (scritti esegetici su) [w:] A. Monaci Castagno, Origene. Dizionario: la cultura, il pensiero, le opere, Roma 2000, s. 195-197, tu: s. 197.

${ }^{36}$ Por. A. Jaubert, Introduction, SCh 71, s. 44-46.

37 Orygenes, Homeliae ..., II, 1, s. 118-119, PSP, s. 13.

38 Orygenes, In Johannem VI, 44, SCh 157, s. 302, ŹMT 27, s. 199. W oryg. oikonomia (zbawcze dzieło Boże).

39 Autor Adversus Marcionem poświadcza, że marcjonizm był ruchem skrajnie niebezpiecznym, gdyż burzył podstawy ciągłości Boskiego zamysłu zbawienia i pomniejszał wartość Prawa danego w Starym Testamencie. W opinii Ireneusza z Lyonu Marcjon nie tylko odrzucał cały Stary Testament, lecz również „przekonywał swoich uczniów, że jest bardziej prawdomówny od apostołów, którzy przekazali Ewangelię"; tenże, Adversus haereses III, 3, 1, SCh 211, s. 30-31 [tłum. własne].

${ }^{40}$ Tertulian, Adversus Marcionem III, 16, 4, CCL 1, s. 529, PSP 58, s. 124.

${ }^{41}$ Tamże, III, 16, 5, CCL 1, s. 529, PSP 58, s. 125.

42 J. Daniélou, Sacramentum Futuri..., s. 203.

${ }^{43} \mathrm{~W}$ mozaikowej dekoracji rzymskiej bazyliki Matki Bożej Większej pojawiają się sceny dotyczące Jozuego. Syn Nuna jawi się na nich jako wódz porównywalny z rzymskimi wodzami i cesarzami. Służy temu przedstawianie go według schematów ikonografii cesarskiej. Por. S. Adamiak, Sześcioksiąg w mozaikach bazyliki Santa Maria Maggiore w Rzymie, „Biblica et Patristica Thoruniensia" 4 (2011), s. 165-179, tu: s. 177-178. 
Jozue to imiennik Zbawcy i jedna z najważniejszych Jego zapowiedzi w Starym Testamencie ${ }^{44}$.

Cyryl Jerozolimski w celach katechetycznych syntetyzuje najpierw dzieje Jozuego i zestawia je z osobą i dziełem Zbawiciela. Punktem wyjścia jest, jak to zawsze bywa, zbieżność imion ${ }^{45}$. Grzegorz z Nyssy przeniósł punkt ciężkości z typologii osoby Jozuego, który zapowiadał Chrystusa, na chrześcijanina, który przez chrzest upodobnił się do Niego ${ }^{46}$.

W tradycji syryjskiej, gdy chodziło o imię Zbawcy, nie brakowało refleksji o charakterze typologicznym ${ }^{47}$. Efrem Syryjczyk w zbieżności imion dostrzega wypełnienie się dzieła zbawienia. ,Jozue, syn Nuna przypomina słodki aromat ${ }^{48}$. To dlatego nie jesteś zwodzony odnośnie dopełnienia się prawdziwego imienia Jezusa"49. Poetyckie porównania wskazują na dopełnienie się planu zbawienia w osobie Chrystusa ${ }^{50}$.

Hilary z Poitiers w sposób równie jednoznaczny rozwija typologię Jozuego: „W samym imieniu Jozue jasno pokazuje się zamysł przyszłej tajemnicy ${ }^{51}[\ldots]$. Imię «Jozue»-Jezus nadał wodzowi, którego wołano przedtem «Auses» [Ozeasz], a który miał kierować ludem zdążającym do Ziemi Obiecanej [...]. To zaś imię już w planach nieba było przygotowane dla wiecznego Wodza"52. Biskup Poitiers mówi o „pierwszym” i „drugim” Jozuem-Jezusie ${ }^{53}$.

${ }^{44}$ L. Reau, Iconographie de l'art chrétien, t. 2: Iconographie de la Bible, 1. Ancien Testament, Paris 1956, s. 219-227.

45 „Dla podzielenia dziedzictwa wyznaczył syn Nuna dwunastu mężów — dwunastu apostołów jako heroldów prawdy, posłał też Jezus na świat cały. Tamten, będąc typem Zbawiciela, ocalił ladacznicę Rahab, ponieważ mu uwierzyła (por. Joz 6,25) — prawdziwy Zbawiciel powiedział: «Celnicy i wszetecznice wyprzedzają Was do królestwa Bożego» (Mt 24,2). Za tamtego, który był typem, na sam głos trąb padły mury Jerycha (por. Joz 6,20) — na słowa Jezusa: «Nie pozostanie tu kamień na kamieniu» (Mt 24,2) runęła naprzeciw nas stojąca świątynia żydowska. Wszakże nie ten wyrok był przyczyną jej upadku, lecz grzechy"; Cyryl Jerozolimski, Catechesis X, 11, PG 33, 676 A-B, BOK 14, s. 138-139.

${ }^{46}$ Por. Grzegorz z Nyssy, De baptismate (passim), PG 46, 419; 422.

${ }^{47}$ Por. np. Afrahat, Demonstratio XXI, 11.

48 Wonności kojarzono nierozerwalnie ze sferą boskości i świętości. Takich porównań używali chociażby Grzegorz z Nyssy (zob. In Canticum Canticorum 1, 1-3) i Cyryl Aleksandryjski (por. De sancta et consubstantiali Trinitate 3).

${ }^{49}$ Hymnus de virginitate 17, CSCO 224, s. 49 [tłum. własne]. Imię ,Jezus” identycznie brzmi po syriacku i hebrajsku. Por. Hymni de nativitate I, 31.

${ }_{50}$ Por. M.C. Paczkowski, Przejście Izraelitów przez Jordan (Joz 3-4)..., s. 52.

${ }^{51}$ Por. Tertulian, Adversus Judaeos 9.

${ }^{52}$ Hilary z Poitiers, De mysteriis II, 2, 5, SCh 19, s. 150-151, PSP 63, s. 228. Zob. M.C. Paczkowski, Przejście Izraelitów przez Jordan (Joz 3-4)..., s. 52.

53 „Jak bowiem pierwszy stał na czele synagogi, tak drugi stoi na czele Kościoła. Jak pierwszy był wodzem w osiągnięciu Ziemi Obiecanej, tak drugi jest wodzem w dziedziczeniu ziemi (cytat z Mt 5,4) [...]. Jak pierwszy jest po Mojżeszu, tak drugi po Prawie. Pierwszy otrzymał polecenie, aby kamiennym nożem wznowić obrzezanie (por. Joz 5,2), Pan, który jest Słowem ostrym (na- 
Postać Jozuego, jako zapowiedź Chrystusa, to temat rozwijany na Zachodzie także przez innych autorów. Traktowano to zagadnienie w klasyczny sposób i raczej skrótowo ${ }^{54}$. Hieronim ze Strydonu opisuje natomiast Jozuego jako „figurę Pana, nie tylko w działaniu, ale i w imieniu" ${ }^{55}$. Egzegeta łaciński z właściwą sobie dozą realizmu przedstawił potem skrótowo czyny następcy Mojżesza, zakładając, że adresatowi listu homonimia i jej znaczenie były doskonale znane.

Oprócz typologii związanej z postacią następcy Mojżesza ${ }^{56}$, jest także inny przykład analizowany przez Euzebiusza z Cezarei. Skupia on swoją uwagę na arcykapłanie Jozuem (Jezusie) wzmiankowanym w Za 3,8. Biskup Cezarei zaproponował inną interpretację. Była ona szczególnie kusząca dla chrześcijan ze środowiska helleńskiego. Główną rolę odgrywało podobieństwo imienia z greckim czasownikiem oznaczającym uzdrowienie. „Ponieważ przychodząc przyniósł ze sobą lekarstwo i zdrowie, nazwano go «Jezusem»"57. Na tej etymologii bazowali inni autorzy palestyńscy ${ }^{58}$. Podobne skojarzenia mogły nasuwać się nawet łacinnikom (salus - Salvator) ${ }^{59}$.

Refleksja patrystyczna dotycząca imienia Zbawiciela podążyła zasadniczo w dwóch kierunkach. Włączono imię „,Jezus” w zbiór nomina sacra, a także czerpano obficie z symboliki bazującej na gematrii.

\section{Nomina sacra, gematria i moc imienia Zbawiciela}

Pomiędzy czcią oddawaną Jezusowi, a wytworami materialnej kultury chrześcijańskiej istnieje ścisły związek. Do naszych czasów dotarły przede wszystkim manuskrypty datowane na drugą połowę II wieku i III wiek. Są w nich widoczne pierwsze starania, aby przedstawić w sposób wizualny wiarę chrześcijańską.

stępuje seria cytatów i aluzji biblijnych: Hbr 4,12; Ef 2,20 oraz Iz 28,16; Rz 2,29) [...]. w sposób duchowy wznowił obrzezanie serca"; Hilary z Poitiers, De mysteriis II, 2, 6, SCh 19, s. 150-151, PSP 63, s. 228. Por. również Tertulian, Adversus Judaeos 9.

${ }_{54}$ Por. np. Augustyn, De civitate Dei XVI, 43, 2; Sermo 293, 11; Cezary z Arles, Sermo 103.

${ }_{55}$ Epistula 53, 8, tekst i tłum. ŹMT 55, t. 2, s. 31-31*. Nawiązanie do Hbr 12,22.

${ }^{56}$ Rolę postaci Jozuego ukazuje etymologia jego imienia, por. Izydor z Sewilli, Allegoriae 72 i De fide catholica 24, 2.

${ }^{57}$ Euzebiusz z Cezarei, Demonstratio evangelica IV, 10, GCS 23 (Eusebius Werke VI), s. 168 [tłum. własne].

${ }^{58}$ Por. Cyryl Jerozolimski, Catechesis X, 13; Epifaniusz z Salaminy, Adversus haereses (Panarion) $29,4$.

59 Nastąpiło to jednak dopiero w czasach św. Augustyna. Określenie Salvator formowało się od czasów Tertuliana, który używał go bardzo rzadko, chętniej stosując neologizm Salutificator; por. R. Braun, Deus Christianorum. Recherches sur le vocabulaire doctrinal de Tertullien, Paris $1977^{2}$, s. 493-494. 
Chodzi przede wszystkim o tak zwane nomina sacra ${ }^{60}$. Tworzyły one zbiór słów kluczowych, które były najważniejsze dla pierwszych chrześcijan. To te określenia wyróżniano w układzie pisma. Pisane były w formie skróconej, z charakterystyczną linią nad literami. W ten sposób najwcześniej traktowano słowa: Jezus, Kyrios, Chrystus, Theos. Praktyka nomina sacra była, jak się wydaje, czysto chrześcijańskim wynalazkiem i rozpoczęła się właśnie pisaniem imienia Jezus w formie skróconej („,IH”) ${ }^{61}$. Badacze tego typu świadectw są zgodni, że ta praktyka pisania stanowi odzwierciedlenie pobożności chrześcijan pierwszych wieków, wskazując na szacunek, z jakim traktowano tytuły chrystologiczne i określenia Boga. Jednocześnie te dowody wskazują na to, że traktowano tak samo osobę Jezusa, jak i Boga Ojca objawionego w Starym Testamencie. Stosowanie nomina sacra zainspirowało szczególną wizję i cześć dla imienia Jezus, narzucając niejako określoną konwencję pisarską ${ }^{62}$. Można domniemywać, że imię Zbawcy wyróżniano na piśmie, tak jak w lekturze synagogalnej Imię Boże zastępowano określeniem „Pan”63.

Dla wszystkich posługujących się w basenie Morza Śródziemnego językiem greckim lub łacińskim litery „I” i „H” były inicjałami imienia Jezus. Miały one rzecz jasna „podkreślenie górne”. To symboliczne odwołanie było jeszcze bardziej czytelne w połączeniu z innymi literami. W ten sposób przekaz teologiczny wyrażony przez symbolikę liter stawał się bardziej kompleksowy. Do „I” dodawano na przykład literę „Y”64. Tak więc „I” oraz „,Y” oznaczały Jezusa. Wyraża to lakoniczna sentencja przypisywana Pachomiuszowi: „Czyń dzieła «I» (Iesus), którego w dawnych czasach nazywano "Y» (Jahwe)" ${ }^{\prime \prime}$. Ten prawodawca cenobityzmu egipskiego nakazuje, aby przypisywać Chrystusowi przymioty Boże, co z pewnością miało wydźwięk antyariański.

O oznaczaniu imienia Jezus literami „I” i „H” świadczy wiele znalezisk, zarówno w epoce przedkonstantyńskiej, jak i w późniejszym okresie ${ }^{66}$. Między literami pojawiają się elementy wskazujące na to, że chodzi o Jezusa, Syna Bożego, a nie innego człowieka (najczęściej dodany jest krzyż lub litera „tau”) ${ }^{67}$. Obie litery mogą być ze sobą połączone, tworząc krzyż.

Włączenie w grupę nomina sacra imienia Jezusa było również umotywowane tym, że początkowe litery imienia Jezusa czyli „I” i „H” są tymi samymi, co litery imienia Bożego w Starym Testamencie (חי). Poświadczają to źródła ju-

\footnotetext{
${ }^{60}$ Kwestię tę rozwinął L.W. Hurtado, The Earliest Christian Artifacts..., s. 95-134.

${ }_{61}$ Tenże, The Origin of the Nomina Sacra ..., s. 664-671.

${ }^{62}$ Por. tenże, The Earliest Christian Artifacts..., s. 96-101.

${ }^{63}$ W ślad za tym zwyczajem poszły thumaczenia Septuaginty i Wulgaty.

64 „I”, czyli pierwsza litera imienia Jezus, znaczyła dla Greków „10”.

${ }^{65}$ Hieronymus [pseudo], Epistola ad patrem Cornelium 1, PL 23, 87 A.

${ }^{66}$ Por. E. Testa, Il simbolismo dei giudeo-cristiani..., s. 25-26.

${ }^{67}$ Por. L.W. Hurtado, The Earliest Evidence....
} 
deochrześcijańskie. Jeden z takich tekstów mówi: „Zwiastujący jego narodziny Archanioł Gabriel objawił Dziewicy, że to Dziecię Zbawiciel świata będzie nazywać się Jezus. W tym imieniu, prawdę mówiąc, zostało ukryte niewyrażalne określenie, wyryte na złotej koronie świętej Arki [Przymierza]. Przez znaki «I» (jod: ') ${ }^{68} \mathrm{i}$ «H» (het: $\pi$ ), czyli według liczb: dziesiątej (I) i ósmej (H) [...]. Zostało to obwieszczone przez imię pełnego świętości Jezusa, Pana chwały" ${ }^{\prime \prime}$.

Być może obeznany z tą tradycją Euzebiusz z Cezarei nie miał wątpliwości, że imię Jezus było „czcigodną pieczęcią, ponad wszystkie insygnia [dosł. korony] królewskie" ${ }^{90}$. Miało ono nie tylko symboliczne, ale także ukryte znaczenie. Metropolita Palestyny powołuje się na Ps 67,5 w thumaczeniu Symmacha („W «Ia» Jego imię”) i przekonuje, że „[Psalmista] za pomocą pierwszej sylaby wskazał na imię Zbawcy Jezusa"

Spekulacje na temat liter i liczb stanowiły metodę właściwą dla ówczesnej epoki i pojawiały się w środowisku chrześcijan wywodzących się z kultury greckiej. Symbolika liter według Marka Maga odwołuje się do zasady, że są one elementami całości. Zrodzenie Słowa to wypowiedzenie Imienia ${ }^{72}$. Litery samego Imienia tworzą inne rzeczywistości. W ten sposób rozwija się pełnia bytów (Pleroma).

W tym kontekście podkreślano, że „Jezus” jest niewyrażonym Imieniem Zbawcy. Oznacza Jezusa ziemskiego, czyli tego, który jest objawieniem Logosu na płaszczyźnie materialnej ${ }^{73}$. „Imię ukryte przed wszelkim bóstwem, władzą i prawdą, które Jezus z Nazaretu przybrał w promieniach światła Chrystusa" "74. $\mathrm{W}$ ten sposób gnostycy wyrażali odkupienie. Istniała dla nich zasadnicza różnica pomiędzy Logosem a Jezusem ziemskim.

W aleksandryjskich kręgach gnostyckich Imię było utożsamianie ze świętym Tetragramem. ,[Żydowski] arcykapłan, opatrzony imieniem wyrytym na złotej płytce, był rozpoznawany przez aniołów i archaniołów [...]. Miał imię wyryte w twoim sercu"75. Tego typu teologia imienia posłużyła Klemensowi Aleksandryjskiemu do wskazania niezwykle bogatych powiązań. „Uważa się, że Imię wyryte na złotej płytce jest godne istnieć ponad wszelkim panowaniem i mocą

${ }^{68}$ Literę tę zastępowano często ,waw”; por. B. Bagatti, The Church from the Circumcision..., s. $172-174$.

${ }^{69}$ Joseppi libellus memorialis 151, PG 106, 170 [tłum. własne]. Formuły te przetrwały w modlitwach koptyjskich ku czci Matki Bożej (tzw. Theotokie niedzielne), zob. B. Bagatti, The Church from the Circumcision..., s. 166-167.

70 Euzebiusz z Cezarei, Demonstratio evangelica IV, 17, GCS 23, s. 198 [thum. własne]. Por. również Laktancjusz, Divinae institutiones IV, 17.

${ }^{71}$ Euzebiusz z Cezarei, Commentarius in Ps. 67, 5 (6), PG 23, 686 C-D [tłum. własne].

72 Por. Ireneusz z Lyonu, Adversus haereses I, 14, 1.

${ }^{73}$ Por. tamże I, 15, 2.

74 Tamże, I, 21, 3,SCh 264, s. 339-340.

${ }^{75}$ Klemens Aleksandryjski, Excerpta ex Teodoto 27, 1, SCh 23, s. 114-115, ŹMT 22, s. 44. 
(Ef 1,21; Flp 2,9) [...]. Jest ono wyryte z powodu swojego widzialnego przyjścia. Jest nazywane imieniem Bożym, ponieważ to właśnie dzięki kontemplowaniu dobroci Ojca, Syn działa. Nazywamy [Go] Bogiem, Zbawcą, który jest początkiem wszystkiego, początkiem stworzeń na obraz Boga niewidzialnego, pierwszym przed wszystkimi wiekami, który wycisnął swoje znamię na wszystkim, co zostało po nim stworzone"76. Tak więc Imię to Syn, doskonałe uosobienie Ojca. To Jego imię jest odciśnięte na wszystkim ${ }^{77}$.

Oznaczenie kreski na górze wskazywało na liczbę, a jednocześnie na imię święte. Stąd pierwsze skojarzenia z wartością liczbową liter alfabetu. Ze środowiska judaistycznego wywodzi się gematria, czyli sposób pisania cyfr za pomocą $\operatorname{liter}^{78}$. Tego typu symbolikę liter stosowano również w języku greckim. Odpowiednikami hebrajskimi „I” i „H”79 były jod i hed, dające liczbę $18^{80}$. Liczba ta oznacza po hebrajsku ,życie" ${ }^{\text {. }}$. Chrześcijanie łączyli więc imię Jezusa z życiem, jak to wyraża $\mathrm{J} 20,31^{82}$.

Podobne zabiegi interpretacyjne stosowano w odniesieniu do całych tekstów. Jak się wydaje, Rdz 14,14 stanowił jeden z tekstów zbiorów zwanych Testimonia, a dotyczących imienia Jezus. Według Pseudo-Barnaby liczba „318” odnosi się do sług Abrama, pomagających mu uwolnić jego bratanka Lota z niewoli. Autor komentarza wyjaśnia najpierw znaczenie liczby „18”, a następnie liczby „300”. Pierwsza oznacza po grecku Imię Jezus $(\mathrm{IH}=18)$, a druga — krzyż $(\mathrm{T}=300)$. „Dziesięciu [i] ośmiu wyrażają litery „I” czyli 10 i „H”, czyli 8. Masz więc Jezusa" ${ }^{83}$. Te same liczby były także wymienione w opisie Klemensa Aleksandryjskiego, który wyjaśniał, że ,jota” i „eta” to litery oznaczające Zbawcę ${ }^{84}$. On także zauważył, że harfa o dziesięciu strunach wskazuje na Jezusa jako Logos ${ }^{85}$. Ten wniosek wypływa z gnostyckiego przekonania, że Ogdoada i Dekada oznaczają niewyrażalne pochodzenie Jezusa ${ }^{86}$.

${ }^{76}$ Klemens Aleksandryjski, Stromata V 38, 6-7, GCS 15, s. 252, thum. J. Niemirska-Pliszczyńska, t. 2, s. 35.

77 Por. J. Daniélou, Teologia judeochrześcijańska (Myśl Teologiczna 39), thum. S. Basista, Kraków 2002, s. 220.

${ }^{78}$ Por. E. Testa, The Faith of the Mother Church ..., s. 189-191.

79 Majuskułową grecką ,etę” czytano zazwyczaj jako „h”.

${ }^{80}$ Por. tamże, s. 215.

${ }^{81}$ Por. L.W. Hurtado, The Earliest Christian Artifacts..., s. 116-117.

82 Zob. E. Testa, The Faith of the Mother Church..., s. 194-195.

${ }^{83}$ Epistula Barnabae IX, 8, SCh 172, s. 146-147, POK 10, s. 188.

${ }^{84}$ „Powiadają, że znak Krzyża Pańskiego ma kształt litery oznaczającej liczbę 300, a znowu, że „jota” i „eta” wskazują na pierwsze litery imienia Zbawcy”; Klemens Aleksandryjski, Stromata VI, 84, 1-3, GCS 15, s. 473, tłum. J. Niemirska-Pliszczyńska, t. 2, s. 161.

${ }_{85}$ Por. Klemens Aleksandryjski, Paedagogus II 4, 43.

${ }^{86}$ Odpowiednio to 8 i 10. Na ten temat por. Ireneusz z Lyonu, Adversus haereses I, 14. 
Ta szczególna symbolika utrzymała się po soborze w Nicei. Liczba „318” była interpretowana chrystologicznie, jako znak imienia Jezus. Nawiązywano do wcześniejszej tradycji ${ }^{87}$, by wzmocnić późniejszą opinię Atanazego, że Sobór był przede wszystkim antyariański. Do określenia Nicejskiego Wyznania Wiary dodano liczbę „318”, nadając mu Boski autorytet Jezusa Chrystusa, obecnego w Kościele i działającego w zgromadzeniu soborowym biskupów ${ }^{88}$.

Szczególna cześć dla imienia Jezus miała swoje implikacje w życiu religijnym, społecznym i indywidualnym chrześcijan. Cześć oddawana Chrystusowi jako Panu (Kyrios) ograniczyła zakres oznak kultu i czci, które były dozwolone po przyjęciu wiary chrześcijańskiej. Również konsekwencje teologiczne były bardzo poważne. Świadomość życia w Chrystusie kierowała je na inne tory.

Cześć oddawana imieniu Jezusa sprzyjała rozwojowi symboli wiary i go ukształtowała. Przyznawanie w nich centralnego miejsca Zbawicielowi stanowiło pozytywne wyzwanie we wszystkich aspektach działalności teologicznej i najważniejsze kryterium wiary chrześcijańskiej. Tak pojęty kult osoby Syna Bożego stanowił zadanie etyczne, liturgiczne i angażujące życie całej społeczności chrześcijan w świecie.

Chrześcijaństwo od samego początku występowało przeciwko tradycjom, które weszły do Talmudu. Tam przecież starano się zniweczyć niezwykłość Jezusa, czczonego przez chrześcijan, stąd silne motywy taumaturgiczne i epifanijne w refleksjach na temat Jego imienia.

W wypadku męczenników oddawanie czci Jezusowi było kwestią priorytetową. Wierzącym nakazywano złorzeczyć imieniu Zbawcy, okazać cześć bożkom pogańskim, ofiarując im kadzidło, lub uczcić posąg cesarza. Celem tych gestów miało być zanegowanie chrześcijańskich praktyk i kultu oddawanego jedynemu Bogu i Synowi Bożemu. Konsekwencje oddawania czci Jezusowi były dla Jego wyznawców negatywne i niebezpieczne, począwszy od ostracyzmu otoczenia i wrogości najbliższych, aż do oskarżenia o spiski i zbrodnie karane skazywaniem na śmierć. Motywacją do odważnego wyznawania imienia Jezusa było poczucie więzi z Nim i świadomość Jego mocy ${ }^{89}$.

Do praktyk chrześcijańskich należało umieszczanie na przedmiotach codziennego użytku „świętych liter” i symboli odnoszących się do Chrystusa. Judaizmowi nie było obce zabobonne wzywanie imienia Bożego i pisanie świętych

${ }^{87} \mathrm{Na}$ ten temat por. L.W. Hurtado, The Earliest Christian Artifacts..., s. 114.

${ }^{88}$ W rzeczywistości w Soborze uczestniczyło 250 biskupów. Optowano za symboliczną liczbą „318”, argumentując, że tak jak liczba sług Abrama, tak i uczestniczący w obradach Soboru Ojcowie wskazują na osobę Jezusa Chrystusa Ukrzyżowanego. Chociaż trudno dzisiaj przyjąć taką interpretację tekstu natchnionego, to jednak trzeba zauważyć głębokie przekonanie Ojców I Soboru co do żywej obecności Jezusa Chrystusa. Por. Wprowadzenie w: Dokumenty Soborów Powszechnych, t. 1, opr. A. Baron, H. Pietras, Kraków 2003, s. 23, przyp. 1.

${ }^{89}$ Por. L.W. Hurtado, Homage... 
liter w celach magicznych ${ }^{90}$. Wierni starożytnego Kościoła w pewnym stopniu przejęli podobne zwyczaje, uważając, że imię Zbawiciela ma taką samą moc. W starożytności moc imienia była powszechnie uznawana. Dotyczy to, jak wspomniałem, przede wszystkim tradycji żydowskiej, ale w dużym stopniu także świata hellenistycznego.

Nie brakowało więc praktyk związanych z wymawianiem imienia Jezusa ocierających się o magię. Wywodziły się jednak one $\mathrm{z}$ grup judeochrześcijańskich i gnostyckich, choć nie były obce grupom prostych wiernych ${ }^{91}$. Był to jednak pewien margines. Nadużycia o charakterze zabobonnym nie przeszkadzały starożytnym autorom w zaleceniach wzywania imienia Chrystusa. Już przecież chrzest stanowił wezwanie nad chrzczonym imienia Jezusa i udzielenie jego mocy. Imię ma bowiem swoją własną moc, która objawia się w momencie jego wezwania ${ }^{92}$. Dla niektórych autorów nie było więc istotne, kto wzywa tego imienia. Takie przekonanie wyraża anonimowy autor z III wieku polemizujący ze świętym Cyprianem z Kartaginy. Według niego „nawet ci, którzy czynią nieprawości, mogą działać dobre rzeczy poprzez przebogatą moc imienia Jezusa" ${ }^{93}$. Cała ziemska działalność Zbawcy charakteryzowała się licznymi znakami i cudami, co podkreślali apologeci. Justyn przypominał, że „nawet demony były poddane Jego imieniu, wszystkie potęgi i królestwa lękały się Jego imienia bardziej niż lękają się oni wszystkich umarłych" ${ }^{94}$.

Orygenes z Aleksandrii zastanawiał się nad „tajemniczym znaczeniem imion” i „filozofią nazw”" ${ }^{\prime 95}$. Imię Jezusa „niejednokrotnie w obecności wielu świadków wypędziło z dusz i ciał złe duchy i posiadało władzę nad ludźmi wyzwolonymi od demonów [...] Znawcy zaklęć twierdzą, iż określone skutki wywiera jedynie zaklęcie wypowiedziane $\mathrm{w}$ danym języku, przełożone zaś na inny język jest bezwartościowe i nie ma żadnej mocy. A zatem nie w znaczeniu słów, lecz w ich brzmieniu i charakterze tkwi moc, która dokonuje określonych efektów"96.

Doktor aleksandryjski przekonywał, że cudowne znaki trwają i powtarzają się nie dzięki „chrześcijańskim zaklęciom”, ale przez wzywanie imienia Zbawcy. „Imię Jezusa do dziś uspokaja pomieszane umysły ludzkie, wypędza demony i leczy choroby; ono wywołuje niezwykłą łagodność i umiarkowanie charakteru,

${ }_{90}$ Zob. J. Trachtenberg, Jewish Magic and Superstition. A Study in Folk Religion, Philadelphia $2004^{2}$, s. $72-80$.

${ }_{91}$ Takie przekonania i praktyki przetrwały w Kościele koptyjskim i etiopskim.

92 „Przybądź święte Imię Chrystusa, które jest wywyższone ponad wszelkie imię”; Acta apostolorum apocrypha, Acta Thomae 27, II, 2, s. 142-143, BOK 25, s. 67.

93 „Per nimiam virtutem nominis Jesu”. De baptismate haereticorum 7, PL 3, 1191, BOK 25 , s. 220. Polemista przywołuje tekst Mk 14,27.

94 Justyn, Dialogus cum Tryphone Judaeo 121, 3, PG 6, 757 A, thum. L. Misiarczyk, s. 293.

95 Orygenes, Contra Celsum I, 25, SCh 132, s. 140-142, thum. S. Kalinkowski, Warszawa 1986, s. 53.

96 Tamże I, 25, SCh 132, s. 142, tłum. S. Kalinkowski, s. 53. 
ludzkie uczucia, dobroć i życzliwość w tych, którzy nie dla doczesnych korzyści albo dla zaspokajania ludzkich potrzeb udają, że są chrześcijanami, lecz szczerze przyjmują naukę o Bogu, Chrystusie i przyszłym sądzie"97.

Ten sam autor, mówiąc o posłudze egzorcysty, wyjaśnia, że największą moc odpędzania szatana ma wezwanie imienia Jezusa i przeczytane $\mathrm{z}$ wiarą słowa Ewangelii. „Egzorcyści czerpią siłę nie z magicznych zaklęć, lecz z imienia Jezusa oraz z odczytywania Jego historii [...]. Imię Jezusa ma zresztą taką władzę nad demonami, że wypowiedziane nawet przez grzeszników wywiera niekiedy określony skutek"98.

Orygenes wskazywał jednoznacznie, że w jego czasach Imię Jezusa wywołuje te same skutki, co w czasach Apostołów ${ }^{99}$. Jego teologia i duchowość miały wpływ na późniejszy rozwój monastycyzmu. W myśli Aleksandryjczyka chrześcijaństwo otwierało na realny kontakt z Bogiem żywym i prawdziwym, objawionym w Jezusie Chrystusie i działającym mocą Ducha Świętego.

Za pośrednictwem św. Antoniego, inicjatora życia monastycznego w Egipcie, „wielu [...] uleczył Pan z chorób ciała, a innych uwolnił od demonów” ${ }^{100}$. Ojciec mnichów wzywał ,imienia Jezusa Chrystusa”, aby wyrzucać duchy nieczyste $^{101}$. Nil z Ancyry zalecał, „by nocą czuwać, wzywając najdroższego imienia Jezusa" ${ }^{102}$. Powtarzał często to zdanie ${ }^{103}$. Imię Zbawcy to najskuteczniejszy oręż w zmaganiach duchowych. „Bombarduj nieustannie przeciwników imieniem Jezusa. Nie ma na ziemi ani w niebie potężniejszej broni"104, przekonywał Jan Klimak. Ten aspekt jest tym bardziej wart podkreślenia, że w literaturze monastycznej najczęściej używa się określeń „Chrystus” i „Pan”. Imię „Jezus” pojawia się rzadko ${ }^{105}$.

Hagiografia monastyczna przytacza przykłady egzorcyzmów i uzdrowień dokonywanych w imię Jezusa Chrystusa. Był to jeden ze stałych elementów pojawiających się w żywotach świętych ascetów ${ }^{106}$.

Jan Chryzostom miał doświadczenie życia monastycznego i znał to środowisko. Zaleca jednak wszystkim wiernym, by wzywali Chrystusa w chwilach pokusy i słabości. „Jeśli będziesz umiał zakląć go [węża — szatana] świętymi

97 Tamże I, 67, SCh 132, s. 266, thum. S. Kalinkowski, s. 84.

98 Tamże I, 6, SCh 132, s. 92-93, thum. S. Kalinkowski, s. 39.

${ }_{99}$ O tym, że imię Jezus pokonuje demony, wzmiankuje Euzebiusz z Cezarei; por. Demonstratio evangelica III, 6 .

100 Atanazy, Vita Antonii 14, SCh 400, s. 174-175, thum. Z. Brzostowska i in., s. 65.

${ }_{101}$ Por. tamże 40, 63, 71, SCh 400, s. 244-245, 302-303, 320-321.

102 Nil z Ancyry, Epistolarum liber II, 214, PG 79, 312 C-D [tłum. własne].

103 Por. tamże II, 140; III, 33.

104 Jan Klimak, Scala paradisi XXI, PG 88, 945 D [tłum. własne].

105 Nigdy nie pojawia się w Regule św. Benedykta.

106 Por. Vitae Patrum Jurensium I, 55; II, 81; III, 142; 144; Konstans z Lyonu, Vita S. Germani II, 10 . 
wyzwaniami, natychmiast zostanie porażony. Dysponujemy przecież duchowymi zawołaniami: imię Pana naszego Jezusa Chrystusa i moc Krzyża. To wezwanie nie tylko wyprowadza smoka z jamy i wrzuca go do ognia (por. Dz 28,5), lecz także goi nasze rany [...]. Imię [Jezusa] jest straszne dla diabłów, namiętności i chorób. Przystrajajmy się więc w nie i nim się obwarowujmy!"107.

Wykonywanie codziennych obowiązków i przemawianie w imię Pańskie jest gwarancją powodzenia. Wielki kaznodzieja z Antiochii tak oto pouczał lud: „Gdzie jest imię Pana, tam dzieje się wszystko szczęśliwie. Jeśli imiona konsulów udzielają pismu pewnej gwarancji, to tym bardziej czy nie jest tak z imieniem Chrystusa? Apostoł chce to powiedzieć: Mówcie i czyńcie wszystko z Bogiem [...]. Wszystko, przy czym to imię jest wzywane, dzieje się pomyślnie"108. Biskup starał się przedstawiać pozytywnie naukę chrześcijańską, a swoje homilie głosił w sposób przystępny i trafiający do słuchaczy ${ }^{109}$.

Moc imienia Syna Bożego unicestwiała także mądrość tego świata, co ukazał epizod z życia Aleksandra, biskupa Konstantynopola z IV wieku. Zwyciężył on w dyskusji z wyrafinowanymi intelektualistami pogańskimi nowej stolicy Imperium. Choć cierpliwie słuchał ich wywodów, w pewnej chwili wypowiedział $\mathrm{z}$ mocą imię Jezusa i to spowodowało zamieszanie wśród pogan ${ }^{110}$. Ten cud sprawił, iż filozofowie musieli zamilkną́ćc111.

Rufin z Akwilei opowiada historię nawrócenia ludu Iberów. Zapoczątkowała je bezimienna niewolnica chrześcijańska ${ }^{112}$, która w imię Syna Bożego dokonywała cudów uzdrowień. Wśród tych, którzy tego doświadczyli była także sama królowa. Gdy prosiła o pomoc w chorobie, chrześcijańska niewolnica „wezwawszy imienia Chrystusa, sprawiła, że natychmiast po modlitwie królowa wstała zdrowa i rześka [...]. [Jezus], bowiem królom rozdaje królestwa, a śmiertelnikom życie"113.

Historyk Grzegorz z Tours, opowiadając o nawróceniu Chlodwiga, wskazuje na to, że ten pogański władca Franków powołał się na imię Zbawcy w trudnych chwilach decydującej bitwy: „Jezusie Chrystusie [...]. [Ty] uchodzisz za przynoszącego pomoc tym, którzy są w nieszczęściu i udzielasz zwycięstwa pokładającym w Tobie ufność, powołując się na sławę Twojej mocy, gorąco pragnę

107 Jan Chryzostom, Homilia in Romanos VIII, 7, PG 60, 463, thum. T. Sinko, s. 133.

108 Tenże, Homilia IX, 3 (in Colossenses 3, 16-17), PG 62, 364, thum. W. Kania, s. 85.

109 Por. P. Retink, La cura pastorale in Antiochia nel secolo IV, Roma 1970, s. 19-56.

${ }^{110}$ Od II wieku apologeci chrześcijańscy sukcesywnie powiększali arsenał środków, jakimi wykazywano sprzeczności czy błędy pogańskich filozofów i poetów. Wiara chrześcijańska, która pokonuje fałszywą mądrość, to topos literacki obecny w hagiografii (motywy dyskusji św. Katarzyny Aleksandryjskiej z filozofami) i literaturze monastycznej (por. np. Vita Antonii 72 Atanazego).

${ }_{111}$ Por. Teofanes, Chronografia XXIII, 7; Ch. Kannengiesser, Alessandro di Costantinopoli, NDPAC, t. 1, 205.

112 Utożsamia się ją ze św. Nino (Niną) lub Krystyną (tj. chrześcijanką).

113 Rufin z Akwilei, Historia ecclesiastica I, 10, PL 21, 481 A [tłum. własne]. Wydarzenia te miały miejsce ok. 330 roku. 
wierzyć Ci i w imię Twoje ochrzcić się, jeżeli mi udzielisz zwycięstwa nad tymi nieprzyjaciółmi, jeżeli doświadczę Twojej mocy, którą o Tobie głoszą ludzie, od Twojego imienia nazwani""114. Zwycięstwo w imię Chrystusa było dla niego znakiem od Boga. Dlatego po tym fakcie „upomniał naród i, powróciwszy do domu po nastaniu pokoju, opowiedział królowej, w jaki sposób, przez wezwanie imienia Chrystusa (per invocationem nominis Christi) osiągnął zwycięstwo" 115.

U zarania chrześcijaństwa wszyscy wierzący wzywali imienia Jezusa. Pod koniec starożytności podkreślano, że czynili to pobożni cesarze, ale także władcy ludów ościennych. Cudotwórcza moc imienia Zbawiciela doprowadzała ich do wiary, a w ślad za władcą szedł cały jego lud.

\section{Teologiczne znaczenie imienia Zbawiciela}

W wielu wersetach Nowego Testamentu pojawia się określenie „Imienia” (por. Dz 15,17; Rz 2,24 i 9,17). Może ono reprezentować wyłącznie Jahwe. Teksty te jednak zostały zgrupowane w antologiach mesjańskich, więc „Imię” pojawia się w związku z Chrystusem. Wczesna literatura chrześcijańska wskazuje na wyraźnie chrystologiczne znaczenie tego określenia (np. cytat z Iz 52,5). „Naśladujcie przykład Pana. Biada temu, kto sprawia, że inni bluźnią imieniu Pana ${ }^{116}$. Klemens Rzymski mówi o „Najświętszym i chwalebnym”, „wszechmocnym” i „najwspanialszym imieniu" 117 .

Teologia imienia ma pochodzenie kultyczne i wyraża się przez formuły liturgiczne, wywodzące się ze wspólnoty nowotestamentowej. Można mówić również o pochodzeniu kosmologicznym, którego początków upatruje się w schyłkowym judaizmie ${ }^{118}$.

Dla judeochrześcijan „Imię” staje się par excellence określeniem Chrystusa i wskazaniem na Jego tajemnicę. Oznacza więc również osobę Tego, który jest wyznawany ${ }^{119}$. Prawdę o Synu Bożym Ignacy z Antiochii ujmował deklaratywną formułą: „Bóg nasz Jezus Chrystus”"120.

114 Grzegorz z Tours, Historia Francorum II, 30, PL 71, 225 B-C [tłum. własne]. Christiani od Christus, a więc tak nazywani przez wzgląd na Jego imię.

115 Tamże, II, 30, PL 71, 226 A [tłum. własne].

116 Zob. Epistula Polycarpi X, 1-3; J. Daniélou, Teologia judeochrześcijańska, s. 207.

117 Klemens Rzymski, Epistula ad Corinthios 58, 1; 60, 4, SCh 167, s. 192-193, 198-199, POK 10, s. 77, 80; por. J. Daniélou, Teologia judeochrześcijańska, s. 209.

118 J. Daniélou, Teologia judeochrześcijańska, s. 211.

119 Ignacy z Antiochii, Epistola ad Ephesios 1,2; 3,1; 7,1, SCh 10, s. 68-71, 74-75, POK 10, s. 113-115 (passim); por. J. Daniélou, Teologia judeochrześcijańska, s. 214.

${ }^{120}$ E. Stanula, Jezus Chrystus - historyczność, (zob. C. Bartnik i in., Jezus Chrystus, kol. $1300)$. 
Syn Boży nie tylko posiada imię, ale jest Imieniem. To pozwoliło uczynić teologii kolejny krok. Imię nie oznacza jedynie Boga w sobie samym, ale również objawiającego. Imię jest identyczne z osobą Syna, objawia więc Jego naturę. Można wręcz odnieść wrażenie, że dla Hermasa Imię jest czymś nad wyraz realnym, mającym swój status ontologiczny. Według Pasterza imię Syna Bożego ,jest wielkie i nieskończone [...]. Podtrzymuje ono cały świat ${ }^{121}$. Autor jednak nie wymienia określenia „Chrystus” czy „Jezus”122.

Ojcowie Kościoła zwracali uwagę na to, że to Syn objawia niewidzialnego Ojca. „Nie można nadać imienia Ojcu wszechświata” ${ }^{23}$, pisze Justyn. To powód, dla którego wszystkie teofanie Starego Testamentu są przypisywane Słowu. Czyni to już święty Ireneusz z Lyonu.

Biskup Lyonu poświadcza ponadto, z jakim typem refleksji na temat tożsamości Chrystusa ma się do czynienia w przypadku gnostyków. W pewnym stopniu przyjęli oni spekulacje judeochrześcijańskie. Dla nich jednak różnica określeń oznaczała odmienność w degradujących się eonach. Dla ofitów Jezus został adoptowany, aby Chrystus znalazł czystą powłokę cielesną ${ }^{124}$. Jezus jako zrodzony z Dziewicy przez Boże działanie był najmądrzejszy, najczystszy i najsprawiedliwszy wśród wszystkich ludzi.

Gnoza, mimo swoich dewiacji doktrynalnych, sięgała po wątki bardzo głębokie. Klemens Aleksandryjski pozwala przypuszczać, że dla niektórych gnostyków imię jest niewidzialną częścią Syna Jednorodzonego ${ }^{125}$. Jest ono jakby pieczęcią i znamieniem $^{126}$. Evangelium veritatis wskazuje, że Imię jest imieniem Ojca, a jednocześnie jest odrębne od wszystkich eonów. Syn (Imię) uosabia Ojca, ale jednocześnie jest od Niego odrębny. „Ojciec sam zrodził Go dla siebie jako Imię [...], a w Imię Ojca było ponad nimi, jako Pan, ten, który jest prawdziwym Imieniem, niewzruszony dzięki swej władzy [...]. Owo imię nie należy do słów ani do nazw [...]. Jest ono niewidzialne. Jemu tylko samemu nadał Imię, będąc jedynym, który Go widzi i jedynym zdolnym nadać Mu Imię [...]. [Jego] Imię jest imieniem Ojca, podobnie jak w imię Ojca jest Synem" ${ }^{127}$. Wizja Imienia w Ewangelii prawdy opierała się na opracowanej już i ugruntowanej teologii judeochrześcijańskiej.

Niejednokrotnie zwracano uwagę na znaczenie praktyk pobożnościowych pierwszych chrześcijan i ich znaczenie dla rozumienia osoby Jezusa w kręgach

${ }^{121}$ Hermas, Pastor: Symb. IX, 14, SCh 53, s. 324-325, POK 10, s. 278.

122 Por. A. Grillmeier, Christ in Christian Tradition, transl. J. Bowden, London 1965, s. 49.

123 Justyn, II Apologia 6, 1, PG 6, 453 A, thum. L. Misiarczyk, s. 94.

${ }^{124}$ Por. Ireneusz z Lyonu, Adversus haereses I, 30, 12.

125 Klemens Aleksandryjski, Excerpta ex Theodoto 26, 1, SCh 23, s. 110-111, ŹMT 22, s. 43.

126 Zob. tamże 86, 2; por. J. Daniélou, Teologia judeochrześcijańska..., s. 211.

127 Evangelium veritatis 38, 32-33. 39, J.McConkey Robinson, The Coptic Gnostic Library. A Complete Edition of the Nag Hammadi Codices, t. 1, Leiden-Boston-Köln 2000, s. 110-113, thum. W. Myszor, s. 67. 
Jego wyznawców. Oddawanie Jezusowi czci jako Bogu było znakiem odróżniającym chrześcijan od wspólnoty żydowskiej. Oznaczało to jednocześnie podstawowe zmiany, jeśli chodzi o pojmowanie monoteizmu wywodzącego się ze środowiska biblijnego. Nie był to bynajmniej monoteizm spoganizowany czy zredukowany. Świadczy o tym odżegnywanie się od kultu aniołów, tak popularnego wśród niektórych grup żydowskich czy judeochrześcijańskich ${ }^{128}$.

Kult oddawany Jezusowi, o którym wspomina już Nowy Testament, nie zakładał zredukowania czy pomniejszenia czci oddawanej Bogu Ojcu. Dla uczczenia Zbawiciela i wzywania Jego imienia nie powstawały inne miejsca niż tylko te, w których czczono jedynego Boga. Nie było też mowy o dodaniu jeszcze jednego bóstwa czy tworzenia minipanteonu. Tylko heretycy, tacy jak Marcjon, byli zwolennikami przeciwnej wizji i stanowczego oddzielenia Jezusa od Boga Starego Testamentu. W większości jednak pierwsze grupy chrześcijan uważały za uzasadnione oddawanie czci Jezusowi na równi z Bogiem Ojcem ${ }^{129}$ jak w tradycji biblijno-judaistycznej. Podkreślano jednak, że zanoszono modły i składano ofiary „w imię ukrzyżowanego Jezusa”"130, co miało wydźwięk polemiczny.

Najczęściej imię „Jezus” było thumaczone jako „Zbawiciel”. Takie wyjaśnienie znaczenia imienia „Jezus/Jozue” pojawia się już u Justyna z Nablus ${ }^{131}$. Można przypuszczać, że używano tego określenia, ponieważ było ono szeroko rozpowszechnione w środowisku helleńskim i rzymskim. Mianem tym określani byli najpierw bogowie i herosi, a następnie wodzowie i władcy ratujący ludzi od różnego rodzaju nieszczęśćć ${ }^{132}$.

Autorzy starożytni często stosowali zabieg, by wersety starotestamentowe mówiące o zbawieniu odnieść do Jezusa. Hezychiusz z Jerozolimy uważał, że wyrażenie Ps 51 mówiące o łaskawości Boga (Jego imię jest dobre) odnosi się do Zbawcy. „Rzecz jasna, cóż jest słodszego niż imię Jezusa”? ${ }^{133}$, pyta z żarliwością.

Imię noszone przez Zbawiciela nie mogło być uważane za pospolite czy stanowić przedmiotu bluźnierstw. Chrześcijaństwo od samego początku występowało przeciwko tradycjom, które znalazły się w Talmudzie. Tam przecież starano się zniweczyć niezwykłość Jezusa, czczonego przez chrześcijan, stąd silne motywy taumaturgiczne i epifanijne w refleksjach na temat Jego imienia. Bardzo rzadko imię Jezusa pojawiało się samo, w sensie absolutnym. Widać

128 Por. Kol 2,18; zob. np. Orygenes, Contra Celsum V, 4.

129 Por. R. Bauckham, The Climax of Prophecy, Edinburgh 1993, s. 118-149.

130 Justyn, Dialogus cum Tryphone 117, 5, PG 6, 748 A, thum. L. Misiarczyk, s. 291. Por. Ireneusz z Lyonu, Adversus haereses II, 32, 4.

131 Por. Justyn, Dialogus cum Tryphone 90, 5; 91, 3; 112, 2.

132 Por. O. Cullmann, Die Christologie des Neuen Testament, Tübingen 1975, s. 247.

133 Hezychiusz z Jerozolimy, In Psalmum 51, 7, PG 93, 1208 B [tłum. własne]. 
to szczególnie przypadku epinoiai, czyli tytułów Syna Bożego lub określeń o charakterze chrystologicznym, które rozwinął Orygenes ${ }^{134}$, a następnie autorzy antyariańscy. Zauważyć można wręcz tendencję, by przy sporządzaniu listy tytułów chrystologicznych ${ }^{135}$ opuszczać imię Jezusa. Autorzy wczesnochrześcijańscy łączyli je raczej z tytułem „Chrystus” oraz innymi określeniami biblijnymi i ontologicznymi. Imię Jezusa było postrzegane z reguły jako odwołanie do Jego natury ludzkiej ${ }^{136}$.

Wielcy teologowie z IV i V wieku, mimo gorących dyskusji chrystologicznych, nie poświęcali zbyt wiele miejsca na refleksję nad Imieniem Jezusa. Chociaż zagadnienie to się pojawia, ma jedynie charakter okazjonalny i stanowi tło innych rozważań. Panowało wówczas przekonanie, że wszystko, co dotyczy prawd Bożych, osoby Chrystusa Pana i tajemnicy zbawienia, zawarte jest w natchnionych księgach ${ }^{137}$. Perykopy ewangeliczne pozwalały na rozwijanie refleksji na temat Imienia Jezus ${ }^{138}$ i Jego zbawczej mocy.

Zwraca na to uwagę Cyryl Jerozolimski. „Jezus Chrystus ma podwójne imię: «Jezus», bo jest Zbawicielem, «Chrystus», bo jest Kapłanem. Wiedział o tym Mojżesz, największy z proroków [...]. Pod wielu względami, był Jezus, syn Nawego, wyobrażeniem Chrystusa"139. Biskup Jerozolimy dopełnia ten wywód i thumaczy: „«Jezus» znaczy u Hebrajczyków «Zbawiciel», u Greków «Lekarz» ${ }^{140}$. Jest

${ }^{134}$ Por. J. Daniélou, Messaggio evangelico e cultura ellenistica, trad. C. Prandi, Bolonia 1975, S. 451.

${ }^{135}$ Nie podano do tej pory jednolitej i precyzyjnej definicji tego określenia. Szerokie traktowanie tego pojęcia powoduje, że tytuły chrystologiczne są w znacznym stopniu mnożone i powielane. Była to tendencja teologii patrystycznej, ale także współczesnych egzegetów i dogmatyków. Opisową definicję pojęcia „tytuł chrystologiczny”podaje T. Horak, Imię ,, Jezus ” tytułem chrystologicznym w Liście do Hebrajczyków, „Colloquium Salutis” 21-22 (1993), s. 119-134, tu: s. 120-122; A. Piwowar, Apozycja tytułów chrystologicznych, s. 116-117, przyp. 23.

136 Autorzy wczesnochrześcijańscy wskazywali, że Jezus to ludzkie imię Syna Bożego: ,Jezus jest imieniem oznaczającym człowieka i Zbawiciela", Justyn, II Apologia 6, 4, PG 6, 453 B, thum. L. Misiarczyk, s. 95; por. również Euzebiusz, Demonstratio evangelica IV, 10; 19.

137 Por. P. Lengsfeld, Überlieferung, Tradition und Schrift in der evangelischen und katholischen Theologie der Gegenwart (Konfessionskundliche und kontroverstheologische Studien 3), Paderborn 1960, s. 120-121.

${ }^{138}$ Pewien wpływ miało na to wprowadzenie w Bizancjum w VI wieku wspomnienia Obrzezania Chrystusa. Do Rzymu to święto dotarło w VIII wieku. I. Noye, Jésus (Nom de) [w:] Dictionnaire de spiritualité ascétique et mystique, éd. M. Viller et al., t. 8, Paris 1974, 1113.

139 Cyryl Jerozolimski, Catechesis X, 13, PG 33, 677 B-C, BOK 14, s. 139.

${ }^{140} \mathrm{~W}$ refleksjach chrześcijańskich przywoływano wizerunek Chrystusa lekarza, opierając się na Mt 9,12 („Nie potrzebują lekarza zdrowi, lecz ci, którzy się źle mają”) i porównaniach medycznych stosowanych przez autorów klasycznych. Wątek ten był popularny w literaturze starochrześcijańskiej (por. np. Ad Diognetum IX, 6; Orygenes, Contra Celsum II, 67; III, 61; In Psalmum 48, 2-3). 
On lekarzem dusz i ciała ${ }^{141}$, przynosi zdrowie duchom. Uzdrawia cieleśnie ślepych, daje światło duszom"142.

Autorzy tego okresu formułują swoje pouczenia o charakterze i znaczeniu imienia Jezus nie tylko na bazie Pisma Świętego, ale także według schematu podanego przez symbol wiary. Taką zasadę stosuje św. Bazyli Wielki. Według jego opinii w formułach wiary istnieje porządek imion Bożych, który powinien pozostać niezmienny ${ }^{143}$.

„«Porodzi [Ona] Syna i nadasz Mu imię Jezus» (Mt 1,21). Imiona tych, którym się je rozmyślnie nadaje, mówią o naturze tego, który je nosi [...]. U każdego (z patriarchów) imię wyrażało nie właściwości ciała, ale ich charakterystyczną cechę. Dlatego i tu nazwany jest «Jezusem», czyli «zbawieniem ludu». Spełnia się też tajemnica, postanowiona przed wiekami i przepowiedziana przez proroków"144. Bazyli cytuje Iz 7,14 ${ }^{145}$ i poświęca dalszą część wywodu egzegezie tego tekstu ${ }^{146}$.

Młodszy brat Bazylego Grzegorz z Nyssy wskazywał na to, że „słowa [Pnp 1,3] oznaczają, iż nie można dokładnie wyrazić znaczeniami imion nieskończonej natury Boga. Żadna siła myśli, żadne znaczenie słów i nazwy choćby zdawały się mieć w sobie coś wielkiego i godnego Boga, ze swojej natury nie jest w stanie wyrazić Tego, który naprawdę jest"147.

Perykopę ewangeliczną Mt 1,21 analizuje Jan Chryzostom. „Anioł przyniósł z niebios imię [Jezusa], dowodząc tym samym, że to, co poczęte, jest niezwykłe, gdyż sam Bóg przysłał Józefowi imię przez anioła. Nie jest ono zwyczajne, lecz jest skarbnicą niezliczonych dóbr. Dlatego anioł je wyjaśnia i roztacza piękne nadzieje, również tym sposobem skłaniając go [tj. Józefa] do wiary"148. Wśród dóbr, które miało przynieść mające narodzić się Dziecię ${ }^{149}$, jest „wybawienie i zgładzenie grzechów. «On bowiem», zapowiada, «zbawi

141 Kontekst opisuje J. Moles, Jesus the Healer..., s. 130.

142 Cyryl Jerozolimski, Catechesis X, 12, PG 33, 677 A-B, BOK 14, s. 139. Po przyjęciu katechumenów nazywano ich tymi, którzy „mają być oświeceni” (gr. fotizomenoi). Chrzest był nazywany „oświeceniem”.

143 „W kwestii nazw — precyzuje Bazyli, odwołując się do kwestii zbawczego imienia Bożego — jest dla nas wystarczające uznać te [z nich], które otrzymaliśmy z Pisma Świętego [...]. Nie w wymyślaniu określeń jest nasze zbawienie, ale we właściwym wyznawaniu Boskości, w którą wierzymy"; Bazyli Wielki, Epistula 175, Y. Courtonne, t. 2, s. 112 [tłum. własne].

144 Bazyli Wielki, In sanctam Christi generationem 4, PG 31, 1465 B [tłum. własne].

145 Por. również Mt 1,23.

146 Bazyli odwołuje się do Bar 3,38. Wcześniejsze przykłady egzegezy Iz 7,14 to np.: Justyn, Dialogus cum Tryphone 84,3; Ireneusz z Lyonu, Adversus haereses III, 21, 6.

147 Grzegorz z Nyssy, In Canticum Canticorum I, 3, Gregorii Nysseni opera 6, s. 262, ŹMT 43, s. 34 .

148 Jan Chryzostom, Commentarius in S. Matthoum Evangelistam IV, 7 (1, 17-21), PG 57, 47, ŹMT 18, s. 59.

149 Złotousty streszcza wcześniej poprzednią sekcję homilii (IV, 6). 
swój lud od jego grzechów» (Mt 1,21) [...]. Ogłasza wybawienie nie od widocznych dla oczu konfliktów zbrojnych, ani od barbarzyńców, ale - co jest o wiele większe - wybawienie od grzechów, czego nie mógł uczynić nikt przedtem" $" 150$. Kontynuując swoje rozważania soteriologiczne, Złotousty podkreśla powszechność zbawienia skierowanego do pogan. To stanowi temat jego nauczania.

Inni Ojcowie, którzy manifestowali pobożność Imienia Jezusa, skupiali się na kwestiach życia wewnętrznego. Tak było w przypadku mnichów oraz Efrema Syryjczyka. Był on przekonany, że „Jezus to imię godne chwały, niewidzialny most prowadzący ze śmierci do życia" ${ }^{151}$. Na początku strofy umieszczona jest litera yod, rozpoczynająca imię Jezusa po syryjsku ${ }^{152}$. Kompozycja wskazuje na to, że jest niedokończonym akrostychem. To być może czytelny znak, że poeta syryjski porzuca zbędną refleksję nad niewyrażalnymi tajemnicami dotyczącymi osoby Syna ${ }^{153}$. Może również chodzić o związek dwóch Osób Boskich (Ojca i Syna). Wobec niezgłębionych tajemnic pozostaje ufna wiara, na którą Efrem jednoznacznie wskazuje.

W kręgu poetów łacińskich poemat o Imieniu Chrystusa napisał Paulin z Noli ${ }^{154}$. To Imię jest „w ustach niczym nektar, miodem na języku”; jest „żywą ambrozją, jeśli ktoś raz go skosztował, to nie może się od niego oderwać, dla oczu jest jasnym światłem, dla uszu brzmieniem życia" ${ }^{155}$.

Hilary z Poitiers korzystał z dziedzictwa refleksji Ojców greckich. Wskazuje on na to, że „nasz Pan Jezus Chrystus jest Bogiem w następujący sposób: ze względu na imię, przez narodzenie [z Ojca], z powodu natury, ze względu na moc i świadectwo. Myślę, że jeśli chodzi o imię nie ma [co do tego] wątpliwości”'156.

Po przywołaniu J 1,1 Hilary kontynuuje: „Jakże jest fałszywym twierdzeniem, że on nie byłby Bogiem, którego nosi imię? Czy może [ono] nie oznacza natury? [...]. Chodzi bowiem o imię nadane w sposób prosty, bez dodatków ze-

150 Jan Chryzostom, Commentarius in S. Matthceum Evangelistam IV,7 (1, 17-21), PG 57, 47, ŹMT 18, s. 59. Antiocheńczyk przypominał wiernym: „Nie patrzcie na wielkość swych win, nie myślcie o grzechach, lecz znając wspaniałomyślność Pana, zwróćcie uwagę raczej na wzniosłość Jego łaski i wielkość daru"; Catechesis I, 18, SCh 50, s. 118, tłum. W. Kania, s. 29.

${ }^{151}$ Efrem Syryjczyk, Hymni de fide VI, 17, CSCO 154, 31-32 [tłum. własne]. Zob. T. Koonammakkal, Ephrem on the Name of Jesus, „Studia Patristica” 33 (1997), s. 548-552.

${ }^{152} \mathrm{Na}$ ten temat por. A.N. Palmer, Restoring the ABC in Ephraim's cycles on Faith and Paradise, „The Journal of Eastern Christian Studies” 55 (2003), s. 147-194, tu: s. 160-161.

${ }^{153}$ Litera yod to symbol nieskończoności i metafora wcielenia, por. Efrem Syryjczyk, Hymni de nativitate $\mathrm{XXV}, 10$.

154 Ten poemat stanowił być może inspirację dla św. Bernarda z Clairvaux. Warto dodać, że papież Damazy (366-384) niektóre epigramaty poświęcił imieniu Jezusa.

155 Paulin z Noli, Poema II: De nomine Iesu 751-752, PL 61, 741 [tłum. własne].

${ }^{156}$ Hilary z Poitiers, De Trinitate VII, 9, SCh 448, s. 292-293, PSP 64, s. 207. 
wnętrznych, które mogłyby stanowić przeszkodę ${ }^{157}$. Słowo, które «stało się ciałem», nie jest nikim innym, jak tylko Bogiem. Nie ma żadnego podejrzenia przypisania [imienia] czy przybrania [go] w sensie czysto nominalnym, tak iż można by myśleć, że nie posiada imienia Bożego z natury"158.

Święty Ambroży z Mediolanu uważał, że święte imię było zamknięte w Izraelu, jak woń pachnidła w naczyniu. Zostało ono jednak otwarte i cudowna woń rozeszła się na cały świat ${ }^{159}$. Chrystus, udzielając Ducha Świętego, dokonuje prawdziwego „wylania Imienia"160. To dowód nadzwyczajnej łaski, ponieważ „Z obfitości wypływa to, co się wylewa (ex abundantia superfluit quidquid effunditur)" ${ }^{\prime 161 .}$

Święty Augustyn, chociaż sporadycznie wspomina o znaczeniu imienia Jezusa, czyni to jednak, komentując tekst z księgi Habakuka: „Rozraduję się w Bogu, moim Zbawcy" (Ha 3,18) ${ }^{162}$. Czyni to pod koniec De civitate Dei, gdy odnotowuje ciekawy wariant tekstu biblijnego, do którego wprowadzano imię Jezusa.

„W niektórych tekstach mamy w tym miejscu słowa: «Będę się cieszył w Bogu, Jezusie mym» (gaudebo in Deo, Iesu meo). Jak mi się wydaje, jest to ujęcie lepsze od spotykanego u tych, którzy chcąc wszystko przetłumaczyć na łacinę, nie przytoczyli Imienia Jezusa; a wszak wymawianie tego Imienia jest dla nas tak przyjemne i tak miłe!"'163.

Ścisły związek pomiędzy łacińskim salutaris czy Salvator (Zbawiciel) i hebrajskim imieniem Jezus uwiarygodnia tę wersję. Biskup Hippony z reguły analizuje tytuły chrystologiczne, w tym imię Zbawiciela, w kontekście kaznodziejskim. Wtedy z całą swobodą sięga do Pisma Świętego. Używa jednak regularnie uroczystej formuły „Jezus Chrystus, nasz Pan”164. Wyjaśnia w sposób jednoznaczny: „Inne znaczenie ma «Jezus», a inne «Chrystus», a jest jeden Zbawca nasz, Jezus Chrystus. «Jezus» to jego właściwe imię [...]. «Chrystus» to imię oznaczające tajemnicę"165.

${ }^{157}$ Kiedy imię zostaje dane w sposób prosty i bezpośredni, a więc bez dodatków i wyróżnień ograniczających jego stosowanie, oznacza wówczas naturę danej rzeczywistości. Na temat ogólnej zasady, według której imię oznacza rzeczywistość, zob. Hilary z Poitiers, De Trinitate II 3.

158 Tamże, VII, 9, SCh 448, s. 294-295, PSP 64, s. 207.

159 Biskup Mediolanu robi aluzję do Pnp 1,3 i Ps 76,1.

${ }^{160}$ W Pnp 1,3 Orygenes dopatruje się pewnego proroctwa. „Stanie się tak, iż w chwili przyjścia Pana naszego i Zbawiciela, Jego imię rozszerzy się na całą ziemię i na świat cały, tak że będzie miłą wonią na każdym miejscu"; In Canticum homilia I, 4, SCh 37, s. 68, tłum. S. Kalinkowski, s. 201.

${ }_{161}$ Ambroży z Mediolanu, De Spiritu Sancto I VIII, 96, SAEMO 16, s. 124-125 [tłum. własne].

162 „Gaudebo in Deo, salutari meo”.

163 Augustyn, De civitate Dei XVIII, 32, PL 41, 561, thum W. Kornatowski, t. 2, s. 355-356.

164 Por. Augustinus-Lexikon, ed. C. Mayer, K.H. Chelius, t. 1, Basel 1986, 870. Zob. zakończenie Sermo 136: „Panie Jezu, cierp za nas”!, tamże, 6, NBA 31/1, s. 260-261.

165 Augustyn, In epistulam Joannis ad Parthos tractatus III, 6, NBA 24/2, s. 1692-1695, PSP 15, s. 413. 
Podczas kazania w uroczystość świętych Piotra i Pawła Hippończyk zwrócił uwagę na $1 \mathrm{Tm}$ 1,15. „Chrystus Jezus to Zbawiciel [...]. Niech nie dociekają gramatycy, czy to po łacinie, lecz niech czynią to w prawdzie chrześcijanie. Zbawienie (salus) to określenie łacińskie. Zbawiać i zbawienie nie istniały w języku łacińskim, zanim nie przyszedł Zbawiciel (Salvator). Przybywając do Latynów uczynił to po łacinie"166. Augustyn powraca do tematu zbawienia niejednokrotnie, często $\mathrm{w}$ polemice z pelagianami ${ }^{167}$.

W komentarzu do Ewangelii Janowej Doctor gratiae wyjaśniał:

„W imię moje, którym jest Jezus Chrystus. Chrystus — znaczy Król, a Jezus — Zbawiciel. O cokolwiek więc prosimy, w imię Zbawiciela prosimy. Jednak On sam jest Zbawicielem nie tylko wtedy, kiedy spełnia to, o co prosimy, lecz także wówczas, gdy tego nie czyni [...]. Wie bowiem lekarz, o co powinien prosić chory, aby odzyskać zdrowie, a co mu szkodzi. Dlatego nie spełnia woli tych, którzy proszą o to, co im szkodzi, aby ich uzdrowić"168.

Wśród innych pisarzy łacińskich Piotr Chryzolog w swoim przepowiadaniu daje świadectwo żywego zainteresowania sprawami doktrynalnymi i teologicznymi, przede wszystkim chrystologicznymi ${ }^{169}$. Jest tak w Mowie $57^{170}$, gdzie biskup Rawenny wyjaśnia:

Podobnie, jak królowie otrzymują tytuły z racji ich zwycięstw i przydaje się im liczne przydomki od nazw pokonanych ludów, tak samo i Chrystus jest nazywamy określeniami swoich łask. Od oliwy nazywany jest „Chrystusem”, ponieważ jako litościwy lekarz wylał oliwę swego bóstwa na członki obumarłe śmiertelnych ludzi [...]. Nazywano Go „Jezusem” od „zbawienia", ponieważ po to nas namaścił boskim olejkiem, aby chorym dać pewne wybawienie, a temu, kto był już spisany na straty trwałe zdrowie ${ }^{171}$.

W innym kazaniu Chryzolog nawiązywał do Mt 1,20, odwołując się przede wszystkim do litery tekstu i harmonii tekstów Nowego Testamentu (Łk 1,31 i listy Pawłowe).

„Nazwiesz go imieniem Jezus” (Łk 1,31). Dlaczego Jezus? Niech to powie apostoł: „Aby w imię Jezusa zgięło się każde kolano [...]" (Flp 2,10). A ty niegodziwy badaczu wszystkiego $^{172}$, pytasz teraz kim jest Jezus? Każdy język głosi, że Pan Jezus jest w chwale Boga Ojca, a ty jeszcze teraz dociekasz złośliwie, kim jest Jezus? ${ }^{173}$.

166 Tenże, Sermo 299, 6, NBA 33, s. 376-377 [thum. własne].

167 O znaczeniu zbawczej śmierci Chrystusa por. Sermo 136, 6.

168 Augustyn, In Joannis evagelium tractatus LXXIII, 3, NBA 24/2, S. 1192-1195, PSP 15, S. $151-152$.

169 Por. R. Benericetti, Il Cristo nei sermoni di S. Pier Crisologo, Cesena 1995.

170 Piotr Chryzolog, Sermones 56-62 stanowią wyjaśnienie Credo.

171 Tenże, Sermo 57, 5, OdSPC, t. 1, s. 384-385 [tłum. własne].

172 Bazyli Wielki krytykował tych chrześcijan, którzy „,ciągle jeszcze poszukują [...], czy to [przyjęte] człowieczeństwo było doskonałe lub niedoskonałe”; tenże, In sanctam Christi generationem 2, PG 31, 1461 C [tłum. własne]; por. również tenże, Epistula 261, 2.

${ }^{173}$ Piotr Chryzolog, Sermo 145, 8, OdSPC, t. 3, s. 134-135 [tłum. własne]. 
Należy przypomnieć, że cytowane fragmenty Flp przywoływano w okresie kontrowersji apolinarystycznej, często bowiem ta perykopa była manipulowana przez heretyków ${ }^{174}$.

Biskup Rawenny łączy Mt 1,20 i Łk 1,31, by wprowadzić swoje refleksje na tory soteriologiczne. Stawia znak równości pomiędzy zbawieniem a odpuszczeniem grzechów. Jednego i drugiego dokonać może tylko Bóg ${ }^{175}$. Zwraca się w ten sposób przeciwko heretykom. Wydaje się, że chodzi o doktrynę nestoriańską, którą jednak Piotr Chryzolog utożsamia z błędami Ariusza (zaprzeczenie bóstwu Chrystusa). Widać pewną niechęć hierarchy łacińskiego do subtelności rozważań teologów greckich ${ }^{176}$.

Tekst Flp 2,10-11 zwracał uwagę na kwestie pojmowania imienia Zbawcy, co widać u Teodoreta z Cyru. Zdecydował się on na całościowe komentowanie listów Pawłowych. Nie był pierwszym, który poświęcił się egzegezie tych ważnych pism nowotestamentowych ${ }^{177}$. Biskup Cyru nie krył pewnego zakłopotania wobec tak poważnego zadania ${ }^{178}$. Odnośnie do imienia Jezusa syntetyzuje: „Chrystus jako człowiek przyjął to, co wcześniej posiadał, będąc Bogiem. Niektórzy [komentatorzy] «imię» rozumieli jako synonim chwały"179. Biskup Cyru przyznaje jednak, że on doszukuje się „,innego sensu” ${ }^{180}$ : „[Syn Boży] uniżając samego siebie nie tylko nie utracił tego, co posiadał jako Bóg, ale to otrzymał jako człowiek" "181.

Wymowne są wypowiedzi dwóch autorów z V wieku: komentatora Mt utożsamianego z Janem Chryzostomem i Cyryla z Aleksandrii. Anonimowy egzegeta wskazuje, że

Ewangelista wyjaśnia, co oznacza „Jezus” po hebrajsku, mówiąc: „On zbawi swój lud od jego grzechów" (Mt 1,21). Jeśli lekarze, którzy nie mają żadnej mocy, aby uratować istotę ludzką, nie wstydzą się nazywać siebie uzdrowicielami, tylko dlatego, że mieszają zioła, to czyż tym bardziej nie należy nazywać Chrystusa Zbawcą, gdy przez Niego cały świat został zbawiony? ${ }^{182}$.

174 Biskup Rawenny z pewnością znał prawowierną interpretację Flp 2,6-7, przedstawioną przez Hilarego z Poitiers w De Trinitate VIII, 45-46; por. SCh 448, s. 450-455.

175 Zob. Piotr Chryzolog, Sermo 145, 9.

${ }_{176}$ Por. Piotr Chryzolog = G. Banterle [et al.], Opere di San Pier Crisologo. Sermoni [125-179] e Lettera a Eutiche, t. 3, Milano-Roma 1997, s. 135, przyp 5.

177 Por. M.G. Mara, Il significato storico esegetico dei commentari al corpus paolino dal IV al V secolo, „Annali di storia dell'esegesi” 1 (1984), s. 59-74.

178 Por. Teodoret z Cyru, Interpretatio in quatuordecim ep. s. Pauli [prol.].

179 Tamże, Ad Phil. 2,9, PG 82, 572 A, ŻMT 14, s. 92.

180 Biskup Cyru przywołuje teksty Hbr i wskazuje, że odnośnie do nich należy przyjąć autorstwo Apostoła; por. tamże [prol.], PG 82, 44 B.

181 Tamże, Ad Phil. 2,9, PG 82, 572 A, ŻMT 14, s. 92.

182 Opus imperfectum in Matthaeum I, 21, PG 56, 634 [tłum. własne]. 
Cyryl Aleksandryjski dodaje natomiast, że „Jezus czyni wszystko nie dla swej własnej chwały, ale dla ich zbawienia" ${ }^{183}$. Godnym uwagi jest skojarzenie etymologii imienia Zbawiciela $\mathrm{z}$ uzdrawiającym Jezusem ${ }^{184}$. Jego proces rozumowania jest zasadniczo taki sam, jak w przypadku anonimowego komentatora do Ewangelii Mateusza ${ }^{185}$.

\section{Zakończenie}

Typologia Jozue-Jezus miała bardzo solidne podstawy związane z homonimią. Przyczyniła się ona do wprowadzenia wątków chrystologicznych do lektury Starego Testamentu. Nie tylko typologia, ale także refleksje osnute na kanwie numerologii czy znaczenie funkcjonalne nomina sacra wskazywały na potęgę Imienia Jezus. Imię to było przecież epifanią samego Boga. Przyzywano więc moc Imienia Jezus, by walczyć ze złem duchowym i fizycznym. Interpretację egzegetyczno-teologiczną należy z kolei umieścić na tle kontrowersji chrystologicznych. Odżywały one w nowych formach, nawet jeśli zostały oficjalnie potępione i odrzucone. Pierwsi chrześcijanie znacznie częściej niż samego tylko imienia Jezus używali uroczystych tytułów: „Jezus Chrystus”, „Chrystus” albo „Pan” (Kyrios) na określenie boskiej godności Zbawiciela. Pobożność związana z imieniem Jezusa, której słusznie można dopatrywać się u niektórych autorów starożytnych, nie była oparta na emocjach, ale na wierze w moc Syna Bożego i świadomości przynależności do Jego wspólnoty. Aspekt biblijny, ubogacony o elementy duchowości, pozwolił na głębsze wnikanie w tajemnicę Boga-Człowieka.

\section{Reflections on the Name of Jesus in Ancient Christianity}

\section{Summary}

This study opens with a brief reflection on the typological value of the person and name of Joshua in the ancient Church. Christians saw the figure of Joshua as a foreshadowing of the saving work of Jesus Christ. According to patristic vision the order of grace in Jesus Saviour replaces the ancient order of the Law. On the basis of homonymy Joshua is associated with Christ. The intent of the study was also to present the historical beginning of the practice to invocate the Lord's Name. To express the faith in Christ symbolically, the first Christians recurred to the use

183 Cyryl Aleksandryjski, Commentariorum in Matthaeum I, 21 (fragm. 166); cytat wg M. Simonetti, Ancient Christian Commentary on Scripture. New Testament I: Matthew 1-13, Downers Grove (Illinois) 2001, s. 272 [tłum. własne].

${ }_{184}$ Metropolita Egiptu wyjaśnił, że rdzeń imienia Jezusowego (Iao) „Hebrajczycy określają jako zbawienie"; In Matthaeum I, 1, PG 72, 365 A [tłum. własne].

185 Por. M. Simonetti, Ancient Christian Commentary..., s. 141 i 272. 
of numerology and to the nomina sacra. This article argues that the ancient Christian literature contains sustained and substantial references to the name of Jesus as 'Saviour'. It is possible to find the theological finality in the interpretation of Lord's name. At every point of the discussion in the Patristic tradition it is found a considerable richness and significance of the name of Jesus (biblical, doctrinal and spiritual).

\section{Keywords}

Jesus (name of), Patristic spirituality, Christian piety, hagiography, Gospels, symbolism of letters, numerology

\section{Slowa kluczowe}

Jezus (imię), duchowość patrystyczna, pobożność chrześcijańska, hagiografia, Ewangelie, symbolika liter, numerologia

\section{Skróty zastosowane w zapisach bibliograficznych}

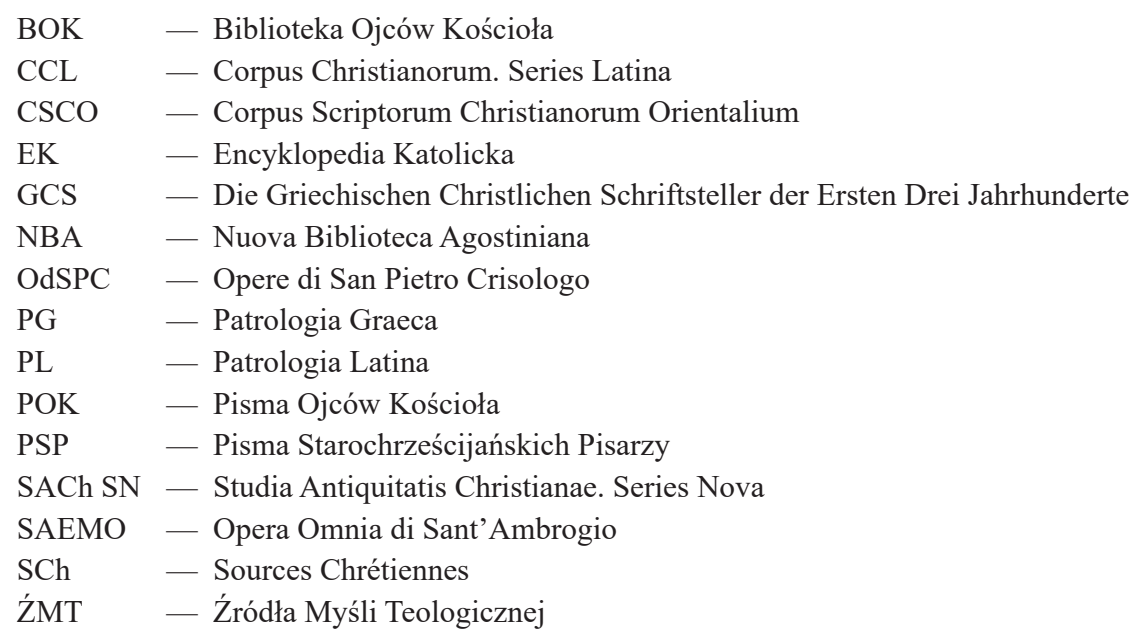

\section{Bibliografia}

\section{Źródla}

Acta apostolorum apocrypha, t. 2, ed. R.A. Lipsius, M. Bonnet, Lipsiae 1903.

Ad Diognetum, ed. H.I. Marrou, SCh 33 bis, Paris, 1965² [wyd. polskie: Do Diogneta, thum.

A. Świderkówna, BOK 10, Kraków 1998, s. 339-349.

Afrahat $=$ Aphraates, Demonstrationes XI-XXIII, ed. M.J. Pierre, SCh 359, Paris 1989.

Ambroży z Mediolanu = Ambrosius Mediolanensis, De Spiritu Sancto, ed. C. Moreschini, Ambrogio di Milano. Opere dogmatiche II, SAEMO 16, Milano-Roma 1984.

Atanazy = Athanasius, Vita Antonii, ed. G.J.M. Bartelink, SCh 400, Paris 2004 [reprint] [wyd. polskie: Św. Atanazy Aleksandryjski, Żywot św. Antoniego, tłum. Z. Brzostowska, A. Ziółkowski, S. Kazikowski, R. Turzyński, wstęp i komentarz E. Wipszycka,Warszawa 1987]. 
Augustyn $=$

Augustinus Hipponensis, De civitate Dei, PL 41, 13-804, [wyd. polskie: Św. Augustyn, O Państwie Bożym. Przeciw poganom ksiag XXII, I-II, tłum. i oprac.W. Kornatowski,Warszawa 1977].

Augustinus Hipponensis, In epistulam Joannis ad Parthos tractatus, NBA 24/2, [wyd.polskie:

Św. Augustyn, Homilie na Ewangelie i Pierwszy list Jana, PSP15, tłum. W. Szołdrski, W. Kania, Warszawa 1977].

Augustinus, Confessiones, ed. M. Pellegrino, C. Carena, Opere di Sant'Agostino. Le Confessioni, NBA 1, Roma 1975 [wyd. polskie: Święty Augustyn, Wyznania, thum. Z. Kubiak, Warszawa 1982].

Augustinus, De Trinitate, ed. A. Trapé, M.F. Sciacca, G. Beschin, Opere di Sant'Agostino. La Trinità, NBA 4, Roma 1970 [wyd. polskie: Św. Augustyn, O Trójcy Świętej, tłum. M. Stokowska, wprow. J. Tischner, posł. i przyp. J.M. Szymusiak (Biblioteka Filozofii Religii), Kraków 1996. Augustinus, Sermones (273-340/A), ed. M. Recchia, Discorsi (273-340/A), NBA 33, Roma 1986. Bazyli Wielki $=$

Basilius Magnus, Epistula 175, ed. Y. Courtonne, Saint Basile. Lettres. Texte établi et traduit, t. 2, Paris 1961, s. 111-112.

Basilius Magnus, In sanctam Christi generationem, PG 31, 1457-1476.

Cezary z Arles =

Caesarii Arelatensis Opera omnia, t. 2, Maredsous 1942 [wyd. polskie: Chrzest i pokuta w Kościele starożytnym. Antologia tekstów I-III w., BOK 25, oprac. J. Słomka, Kraków 2004].

Cyryl Aleksandryjski $=$

Cyrillus Alexandrinus, Commentariorum in Matthceum, PG 72, 365 A-469 D.

Cyrillus Alexandrinus, Thesaurus de sancta et consubstantiali Trinitatete III, PG 75, 31-35.

Cyryl Jerozolimski = Cyrillus Hierosolymitanus, Catecheses, ed. PG 33, 331-1180 [wyd. polskie:

Katechezy przedchrzcielne i mistagogiczne, tłum. W. Kania, BOK 14, Kraków 2000].

De baptismate haereticorum, PL 3, 1184-1204.

Dokumenty Soborów Powszechnych, t. 1, opr. A. Baron, H. Pietras, Kraków 2003.

Efrem Syryjczyk =

Ephrem Syrus, Hymni de fide, ed. E. Beck, CSCO 154, Louvain 1955.

Ephrem Syrus, Hymni de nativitate (Epiphania), ed. E. Beck, CSCO 186, Louvain 1959.

Epifaniusz z Salaminy = Epiphanius de Salamina, Adversus haereses (Panarion), ed. K. Holl, GCS 37, Leipzig 1933.

Epistula Barnabae, ed. R.A. Kraft, P. Prigent, SCh 172, Paris 1971 [wyd. polskie: Pierwsi świadkowie, thum. A. Świderkówna, POK 10, Kraków 1998].

Epistula Polycarpi, ed. P.Th. Camelot, SCh 10, Paris 1951 [wyd. polskie: Polikarp, List do Filipian, PSP 45, tłum. A. Świderkówna, Warszawa 1990, s. 96-102.

Euzebiusz z Cezarei $=$

Eusebius Caesariensis, Commentaria in Psalmos, PG 23, 71 D-1396 A.

Eusebius Caesariensis, Demonstratio evangelica, ed. I.A. Heikel, GCS 23 (Eusebius Werke 6), Leipzig 1913.

Evangelium veritatis, ed. J. McConkey Robinson, The Coptic Gnostic Library. A Complete Edition of the Nag Hammadi Codices, t. 1, Leiden-Boston-Köln 2000 [wyd. polskie: Ewangelia Prawdy, thum. W. Myszor, [= SACh SN] 7, 57-78.

Filon z Aleksandrii, De mutatatione

Grzegorz z Tours = Gregorius Turonensis, Historia Francorum, PL 71, 159-573. 
Grzegorz z Nyssy $=$

Gregorius Nyssenus, De baptismate, PG 46, 415-430.

Gregorius Nyssenus, In Canticum Canticorum, ed. H. Langerbeck, Gregorii Nysseni opera, t. 6, Leiden 1960 [wyd. polskie: Grzegorz z Nyssy, Homilie do Pieśni nad Pieśniami, tłum. M. Przyszychowska, ŹMT 43, Kraków 2007].

Hermas, Pastor, ed. R. Joly, SCh 53, Paris 1968 [wyd. polskie: Pierwsi świadkowie, tłum. A. Świderkówna, POK 10, Kraków 1998].

Hermias Sozomenus, Historia ecclesiastica, ed. B. Grillet, G. Sabbah, A.J. Festugière, SCh 306, Paris 1983 [wyd. polskie: tłum. S. Kazikowski, Sozomen Hermiasz. Historia Kościoła, Warszawa 1989].

Hesychius Hierosolymitanus, Fragmenta in Psalmos, PG 93, 1179-1338.

Hieronymus [pseudo], Epistola ad patrem Cornelium [w:] Epistolae et Verba Mystica, PL 23, 87 A-C.

Hieronim ze Strydonu = Hieronymus, Epistulae (51-79) [wyd. polskie Hieronim ze Strydonu, Listy, t. 2, tekst łac. H. Pietras, tłum. M. Ożóg, ŹMT 55/2, Kraków 2010].

Hilary z Poitiers $=$

Hilarius Pictaviensis, De mysteriis, P. Brisson, SCh 19, Paris 1967 [reprint] [wyd. polskie: Hilary z Poitiers, Traktat o tajemnicach, thum. E. Stanula, PSP 63, Warszawa 2002].

Hilarius Pictaviensis, De Trinitate, ed. J. Doignon, G.M. de Durand, M. Figura, C. Morel, G. Pelland, SCh 448, Paris 2000 [wyd. polskie: Hilary z Poitiers, O Trójcy Świętej, tłum. E. Stanula, T. Kołosowski, PSP 64, Warszawa 2005].

Ignacy z Antiochii = Ignatius Antiochenus, Epistolae ad Ephesios, ed. P.T. Camelot, SCh 10, Paris 1969 [wyd. polskie: tłum. A. Świderkówna, Pierwsi świadkowie, POK 10, Kraków 1998.

Ireneusz z Lyonu $=$

Irenaeus, Adversus haereses, I, ed. A. Rousseau, L. Doutreleau, B. Hemmerdinger, Ch. Mercier, I-II: SCh 263-264, Paris 1979, V: SCh 152-153, Paris 1969.

Irenaeus, Demonstratio, ed. L.M. Froidevaux, SCh 62, Paris 1959 [wyd. polskie: Ireneusz z Lyonu, Wykład nauki apostolskiej, tłum. W. Myszor, ŹMT 7, Kraków 1997].

Izydor z Sewilli =

Isidorus Hispaliensis, Allegoriae, PL 83, 97-130 B.

Isidorus Hispaliensis, De fide catholica, PL 83, 449-538 A.

Jan Chryzostom $=$

Johannes Chrysostomus, Catecheses, ed. A. Wenger, SCh 50, Paris 1970 [wyd. polskie: tłum. W. Kania, Św. Jan Chryzostom, Katechezy chrzcielne (U źródeł katechumenatu 1), Lublin 1993].

Johannes Chrysostomus, Commentarius in Sanctum Matthceum Evangelistam, PG 57, 13-463

[wyd. polskie: Jan Chryzostom, Homilie na Ewangelię wedtug św. Mateusza, thum. J. Krystyniacki, ŹMT 18, Kraków 2000].

Johannes Chrysostomus, In epistulam ad Ephesios, PG 62, 9-176.

Johannes Chrysostomus, In epistulam ad Romanos, PG 60, 13-184 [wyd. polskie: Jan Chryzostom, Homilie na List św. Pawła do Rzymian, t. I/1, tłum. T. Sinko, opr. A. Baron, Kraków 1995].

Johannes Chrysostomus, In I ad Timotheum, PG 62, 599-662.

Jan Klimak = Johannes Climacus, Scala paradisi, PG 88, 631-1165.

Józef Flawiusz $=$ Josephus Flavius, Antiquitates Judaicae, ed. H.S.J. Thackeray, R. Marcus, L.H. Feldman, Josephus Flavius. Jewish antiquities, t. 1-9 (The Loeb Classical Library 203; $210 ; 242 ; 281 ; 326 ; 365 ; 410 ; 433 ; 456$ ), Cambridge (Massachusetts) 1966-1982.

Joseppi libellus memorialis, PG 106, 15-176. 
Justyn $=$

Justinus Martyr, Apologia I-II, ed. PG 6, 327-470 [wyd. polskie: Justyn Męczennik, 1 i 2 apologia, Dialog z Żydem Tryfonem, tłum. L. Misiarczyk, BOK 24, Kraków 2004].

Justinus Martyr, Dialogus cum Tryphone Judaeo, PG 6, 471-800 [wyd. polskie: Justyn Męczennik, Dialog z Żydem Tryfonem, thum. L. Misiarczyk, Warszawa 2012].

Klemens Aleksandryjski=

Clemens Alexandrinus, Excerpta ex Theodoto, ed. F.M. Sagnard, SCh 23, Paris 1970 [wyd. Polskie:

Klemens Aleksandryjski, Wypisy z Teodota, thum. P. Siejkowski, ŹMT 22, Kraków 2001].

Clemens Alexandrinus, Paedagogus, ed. O. Stählin, GCS 12, Leipzig 1905 [wyd. polskie: Klemens Aleksandryjski, Wychowawca, thum. M. Szarmach, Torun 2012].

Clemens Alexandrinus, Stromata, V, ed. O. Stählin, GCS 15, Leipzig 1906 [wyd. polskie: Klemens Aleksandryjski, Kobierce zapisków filozoficznych dotyczacych prawdziwej wiedzy, t. 1-2, tłum. J. Niemirska-Pliszczyńska, Warszawa 1994].

Klemens Rzymski = Clemens Romanus, Epistula ad Corinthios, ed. A. Jaubert, SCh 167, Paris

1971 [wyd. polskie: Ojcowie apostolscy, tłum. A. Świderkówna, PSP 45, Warszawa 1990].

Konstans z Lyonu = Constantius, Vita S. Germani, ed. R. Borius, SCh 112, Paris 1965.

Laktancjusz = Lactantius, Divinae institutiones IV, ed. P. Monat, SCh 377, Paris 1992.

Nil z Ancyry = Nilus, Epistolarum liber II, 214, PG 79, 203 A-364 B.

Opus imperfectum in Matthaeum, PG 56, 601-611.

Orygenes $=$

Origenes, Contra Celsum, ed. M. Borret, I-II: SCh 132, Paris 1967, III-IV: SCh 136, Paris 1968, V-VI: SCh 147, Paris 1969, VII-VIII: SCh 150, Paris 1969 [wyd. polskie: Przeciw Celsusowi, thum. S. Kalinkowski, Warszawa 1986].

Origenes, De principiis, I-II, ed. H. Crouzel, M. Simonetti, SCh 52-253, Paris 1978 [wyd. polskie: Orygenes, O zasadach, tłum. S. Kalinkowski, ŹMT 1, Kraków 1996].

Origenes, Expositio quarumdam propositionum ex Epistola ad Romanos, ed. C.P. Hammond Bammel, SCh 543, Paris 2011 [wyd. polskie: Orygenes, Komentarz do listu św. Pawła do Rzymian, thum. i oprac. S. Kalinkowski, PSP 57, Warszawa 1993].

Origenes, Homeliae in librum Jesu Nave, ed. A. Jaubert, SCh 71, Paris 1960 [wyd. polskie: Orygenes, Homilie o Księgach Liczb, Jozuego i Sędziów, thum. S. Kalinkowski, PSP 34/2, Warszawa 1986].

Origenes, In Canticum homiliae, ed. O. Rousseau, SCh 37, Paris 1966 [wyd. polskie: Orygenes. Komentarz do „Pieśni nad pieśniami”. Homilie o „Pieśni nad pieśniami”, tłum. S. Kalinkowski, Kraków 1994].

Origenes, In Johannem, ed. C. Blanc, SCh, 157, Paris 170 [wyd. polskie: Orygenes, Komentarz do Ewangelii św. Jana, ŹMT 27, tłum. S. Kalinkowski, Kraków 2003].

Origenes, In Psalmos, ed. J.B. Pitra, Fragmenta in Psalmos 1-150 (Analecta sacra spicilegio Solesmensi parata), t. 2-3, Paris-Venice-Tusculum 1883-1884 [Farnborough 1966].

Paulin z Noli = Paulinus Nolanus, Poema II: De nomine Iesu, PL 61, 737-742 C.

Philo Alexandrinus, ed. F.H. Colson, G.H. Whitaker, Philo in Ten Volumes (and Two Supplementary Volumes), t. 1-10 (The Loeb Classical Library 226; 227; 247; 261; 275; 289; 320; 341; 363; 379; 381; 401), Harvard University Press, Cambridge (MA) 1949-1971.

Piotr Chryzolog = Petrus Chrysologus, Sermones, a cura di G. Banterle, R. Benericetti, G. Biffi, G. Scimé, C. Truzzi, Sermoni [1-62 bis]; [125-179] e Lettera a Eutiche, OdSPC 1; 33, MilanoRoma 1996-1997.

Rufin z Akwilei = Rufinus Aquileiensis, Historia ecclesiastica, PL 21, 461-540 C, trad. T. Dattrino, Rufino di Aquileia. Storia della Chiesa (Collana di Testi Patristici 54), Roma 1985. 
Tertulian $=$

Tertullianus, Adversus Iudaeos, ed. E. Kroymann, CCL 2, Turnhout 1954, s. 1339-1396 [wyd. polskie: Tertulian, Wybór pism II, tłum. E. Stanula, PSP 29, Warszawa 1983].

Tertullianus, Adversus Marcionem, ed. E. Kroymann, CCL 1, Turnhout 1954, s. 441-726, [wyd. polskie: Tertulian, Przeciw Marcjonowi, tłum. S. Ryznar, PSP 59, Warszawa 1993].

Teodoret z Cyru = Theodoretus Cyrrhensis, Interpretatio quatuordecim ep. s. Pauli, PG 82, 43-226 [wyd. polskie: Teodoret z Cyru, Komentarz do Listu św. Pawła do Rzymian, tłum. S. Kalinkowski, ŹMT 5, Kraków 1997].

Teofanes $=$ Theophanes Confessor, Chronographia, ed. C.G. de Boor, Lipsiae 1883.

Vitae Patrum Jurensium, ed. F. Martine, SCh 142, Paris 1968.

\section{Opracowania}

Adamiak S., Sześcioksiag w mozaikach bazyliki Santa Maria Maggiore w Rzymie, „Biblica et Patristica Thoruniensia" 4 (2011), s. 165-179.

A Dictionary of the Targumim, the Talmud Babli and Yerushalmi and the Midrashic Literature, ed. M. Jastrow, t. 1, London-New York 1903.

Augustinus-Lexikon, ed. C. Mayer, K.H. Chelius, t. 1, Basel 1986.

Bagatti B., The Church from the Circumcision. History and Archaeology of the Judaeo-Christians (Studium Biblicum Franciscanum - Collectio Minor 2), Jerusalem 1984.

Bardski K., Chrystologiczna interpretacja Księgi Jozuego u Orygenesa, „CollectaneaTheologica” 84 (2015) 4, s. 197-202.

Bartnik C., Drączkowski F., Stanula E., Szram M., Jezus Chrystus, EK, t. 7, Lublin 1997, $1287-$ 1442.

Bauckham R., The Climax of Prophecy, Edinburgh 1993.

Benericetti R., Il Cristo neisermoni di S. Pier Crisologo, Cesena 1995.

Braun R., Deus Christianorum. Recherches sur le vocabulaire doctrinal de Tertullien, Paris $1977^{2}$. Cullmann O., Die Christologie des Neuen Testament, Tübingen 1975.

Daniélou J., Les symbols chrétiens primitifs, Paris 1963.

Daniélou J., Messaggio evangelico e cultura ellenistica, trad. C. Prandi, Bologna 1975.

Daniélou J., Sacramentum Futuri. Etudes sur les origines de la typologie biblique, Paris 1950.

Daniélou J., Théologie du judéo-christianisme. Histoire des doctrines chrétiennes avant Nicée, (Bibliotheque du Théologie), Paris 1958 [wyd. polskie: Teologia judeochrześcijańska (Myśl Teologiczna 39), przekł. S. Basista, Kraków 2002].

Dictionnaire de spiritualité ascétique et mystique, t. 8: Doctrine et Histoire, éd. M. Viller, F. Cavallera, J. de Guibert, A. Rayaz, A. Derville, P. Lamarche, A. Solignac, Paris 1974.

Foerster W., 'I $I \sigma o \tilde{v}$, Theological Dictionary of the New Testament, t. 3, ed. G. Kittel, Grand Rapids 1995, s. 284-293.

Grillmeier A., Christ in Christian Tradition, transl. J. Bowden, London 1965.

Horak T., Imię ,,Jezus” tytułem chrystologicznym w Liście do Hebrajczyków, „Colloquium Salutis” 21-22 (1993), s. 119-134.

Hurtado L.W., At the Origins of Christian Worship. The Context and Character of Earliest Christian Devotion, Grand Rapids 2000.

Hurtado L.W., Early Devotion to Jesus. A Report, Reflections and Implications, „Expository Times" 122/4 (2011), s. 167-176. 
Hurtado L.W., Homage to the Historical Jesus and Early Christian Devotion, „Journal for the Study of the Historical Jesus" 1-2 (2003), s. 131-146.

Hurtado L.W., The Earliest Christian Artifacts. Manuscripts and Christian Origins, Grand Rapids 2006.

Hurtado L.W., The Earliest Evidence of an Emerging Christian Material and Visual Culture: The Codex, the Nomina Sacra and the Staurogram [w:] Text and Artifact in the Religions of Mediterranean Antiquity. Essays in Honour of Peter Richardson, ed. S.G. Wilson, M. Desjardins, Waterloo (Ontario) 2000, s. 271-288.

Hurtado L.W., The Origin of the Nomina Sacra: A Proposal, „Journal of Biblical Literature” 117 (1998) 4, s. 655-673.

Jaubert A., Introduction, SCh 71, Paris 1960, s. 9-62 [wyd. polskie: thum. S. Kalinkowski, PSP 34/2, Warszawa 1986, s. 44-46].

Kannengiesser Ch., Alessandro di Costantinopoli, NDPAC, t. 1.

Koonammakkal T., Ephrem on the Name of Jesus, „Studia Patristica” 33 (1997), s. 548-552.

Lampe G.W.H., A Patristic Greek Lexikon, Oxford $1976^{4}$.

Langkammer H., Obraz Chrystusa Zbawcy w listach pasterskich, „Questiones selectae” 25 (2010), s. $23-45$.

Lengsfeld P., Überlieferung, Tradition und Schrift in der evangelischen und katholischen Theologie der Gegenwart (Konfessionskundliche und kontroverstheologische Studien 3), Paderborn 1960.

Léon-Dufour X., Jezus Chrystus [w:] Stownik teologii biblijnej, red. tenże, tłum. K. Romaniuk, Poznań 1990, s. 347-357.

Mara M.G., Il significato storico esegetico dei commentari al corpus paolino dal IV al V secolo, „Annali di storia dell' esegesi” 1 (1984), s. 59-74.

Moatti-Fine J., La Bible d'Alexandrie, t. 6: Jesus (Josue), Paris 1996.

Moles J., Jesus the Healer in the Gospels, the Acts of the Apostles, and Early Christianity, „Histos” 5 (2011), s. 117-182.

Monaci Castagno A., Origene. Dizionario: la cultura, ilpensiero, le opere, Roma 2000.

Nossol A., Jezulogia, EK, t. 7, Lublin 1997, 1285-1287.

Noye I., Jésus (Nom de) [w:] Dictionnaire de spiritualité ascétique et mystique, éd. M. Viller, F. Cavallera, J. de Guibert, A. Rayaz, A. Derville, P. Lamarche, A. Solignac, t. 8, Paris 1974, 1113.

Ordon H., Imię Jezus, EK, t. 7, Lublin 1997, 63-64.

Otranto G., La tipologia di Giosué nel „Dialogo con Trifone ebreo” di Giustino, „Augustinianum” 15 (1975) 1/2, s. 29-48.

Paczkowski M.C., Przejście Izraelitów przez Jordan (Joz 3-4) w interpretacji patrystycznej, „Biblica et Patristica Thoruniensia" 8 (2015), s. 39-73.

Palmer A.N., Restoring the ABC in Ephraim's cycles on Faith and Paradise, „The Journal of Eastern Christian Studies" 55 (2003), s. 147-194.

Piwowar A., Apozycja tytułów chrystologicznych i imienia „Jezus”, „Biblica et Patristica Thoruniensia" 8 (2015) 2, s. 111-128.

Reau L., Iconographie de l'art chrétien, t. 2: Iconographie de la Bible, 1: Ancien Testament, Paris 1956.

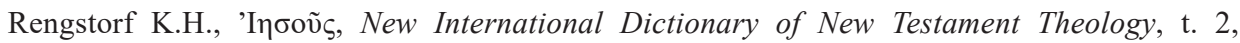
ed. C. Brown, Grand Rapids 1986², s. 330-332.

Retink P., La cura pastorale in Antiochia nel secolo IV, Roma 1970. 
Scognamiglio R., Giosue (scritti esegetici su) [w:] A. Monaci Castagno, Origene. Dizionario: la cultura, il pensiero, le opere, Roma 2000, s. 195-197.

Simonetti M., Ancient Christian Commentary on Scripture. New Testament I: Matthew 1-13, Downers Grove (Illinois) 2001.

Taylor J.E., Christians and Holy Places. The Myth of Jewish-Christian Origins, Oxford 1993.

Testa E., Il simbolismo dei giudeo-cristiani (Studium Biblicum Franciscanum - Collectio Maior 14), Jerusalem 1981.

Testa E., The Faith of the Mother Church. An Essay on the Theology of the Judeo-Christians (Studium Biblicum Franciscanum — Collectio Minor 32), Jerusalem 1992.

Trachtenberg J., Jewish Magic and Superstition. A Study in Folk Religion, Philadelphia 2004².

Tronina A., Jozue — Jezus. Biblijna typologia Zbawiciela, „Verbum Vitae” 1 (2002), s. 41-56.

Turek W., Tertulian (Ojcowie Żywi 15), Kraków 1999.

Vaux de R., Instytucje Starego Testamentu, t. 1-2, tłum. T. Brzegowy, Poznań 2004.

Zorell F., Lexicon Graecorum Novi Testamenti, Paris $1961^{3}$. 